Article

\title{
Geochronology of Magmatism and Mineralization in the Dongbulage Mo-Polymetallic Deposit, Northeast China: Implications for the Timing of Mineralization and Ore Genesis
}

\author{
Fengxiang Wang ${ }^{1,2}$, Qiangfeng $\mathrm{Li}^{2}$, Yifei Liu ${ }^{2}{ }^{-}$, Sihong Jiang ${ }^{2}$ and Chao Chen ${ }^{1, *}$ \\ 1 Key Laboratory of Regional Geology and Mineralization, College of Resources, Hebei GEO University, \\ Shijiazhuang 050031, China; fengxiang@hgu.edu.cn \\ 2 MNR Key Laboratory of Metallogeny and Mineral Assessment, Institute of Mineral Resources, \\ Chinese Academy of Geological Sciences, Beijing 100037, China; liqiangfeng1989@163.com (Q.L.); \\ lyfsky@126.com (Y.L.); jiangsihong@163.com (S.J.) \\ * Correspondence: chenchao@hgu.edu.cn; Tel.: +86-0311-8720-8285
}

Received: 5 March 2019; Accepted: 21 April 2019; Published: 26 April 2019

\begin{abstract}
The recently discovered Dongbulage Mo-polymetallic deposit is located in the southern part of the Great Xing'an Range, northeast China. Mineralization is closely related to the emplacement of Middle-Late Jurassic granitoids. In order to understand the petrogenetic link between mineralization and host granitoids, this study presents new zircon $\mathrm{U}-\mathrm{Pb}$ ages, bulk-rock geochemistry, and molybdenite Re-Os ages for the Dongbulage deposits. LA-ICP-MS zircon U-Pb dating of the monzogranite and syenogranite intrusions yielded two weighted mean ${ }^{206} \mathrm{~Pb} /{ }^{238} \mathrm{U}$ ages: of $164 \pm 2 \mathrm{Ma}$ and $165 \pm 3 \mathrm{Ma}$, respectively. The subvolcanic rocks (red porphyritic granite and rhyolite) yielded a time interval between $161 \pm 2$ and $162 \pm 3 \mathrm{Ma}$. In addition, molybdenite from the Dongbulage deposit gave a Re-Os isochron age of $162.6 \pm 1.5 \mathrm{Ma}$, which was interpreted as the age of the mineralization. The new geochronology has established the close temporal and genetic relationships between the mineralization event and the emplacement of the Middle-Late Jurassic granitoids. Bulk-rock geochemistry shows that the Dongbulage granitoids are characterized by high $\mathrm{SiO}_{2}, \mathrm{~K}_{2} \mathrm{O}$, and $\mathrm{A} / \mathrm{CNK}$ $\left[\mathrm{Al}_{2} \mathrm{O}_{3} /\left(\mathrm{CaO}+\mathrm{Na}_{2} \mathrm{O}+\mathrm{K}_{2} \mathrm{O}\right)(\right.$ molar ratio) $]$ values, and low $\mathrm{TiO}_{2}, \mathrm{CaO}$, and $\mathrm{MgO}$ values, indicating a metaluminous to peraluminous, high-K calc-alkaline affinity. The granitoids also featured enrichments of large ion lithophile elements and light rare earth elements (LREE), and a relative depletion of high field strength elements (HFSE), along with an increasing negative $\delta$ Eu anomaly. The high differentiation index (DI), ranging from 81.75 to 94.76 , and obvious fractionation between LREE and HREE, indicate that the Dongbulage granitoids are highly fractionated, metaluminous-peraluminous, and high-K calc-alkaline I-type granites. Combined with the regional geology, the Dongbulage granitoids may have formed during post-orogenic extension that followed the Mongol-Okhotsk Ocean closure coeval with subduction of the paleo-Pacific plate.
\end{abstract}

Keywords: zircon U-Pb dating; Re-Os dating; middle-late Jurassic; Mo-polymetallic deposit; Great Xing'an Range; Dongbulage

\section{Introduction}

Porphyry Mo-polymetallic deposits are the world's most important source of Mo on account of their large tonnages, and currently account for $<95 \%$ of the global Mo production [1]. The Great Xing'an Range mineral province with a Mo reservoir of $>4$ million tonnes (Mt), which is located at the eastern segment of the Central Asia Orogenic Belt (CAOB), and ranks as the second greatest Mo 
source in China. This region is characterized by abundant highly evolved Mesozoic igneous rocks [2], and contains large-scale Ag-, Sn-, Mo-, and Cu-polymetallic vein deposits (Figure 1a) [3,4]. In this region, seven large base metal $(\geq 0.5 \mathrm{Mt})$ and rare metal $(\geq 0.2 \mathrm{Mt})$ deposits, and 25 smaller $(0.1-0.5 \mathrm{Mt})$ base metal deposits have been discovered [5]. Three newly recognized metallogenic belts are located within the Great Xing'an Range and its adjacent areas. These are: the northern $\mathrm{Mo} \pm \mathrm{Cu}$ ore-forming belt; the middle $\mathrm{Sn} \pm \mathrm{W} \pm \mathrm{Ag}$ metallogenic belt; and the southern Mo ore-forming belt (Figure 1b) [6]. The recently discovered Dongbulage deposit is located where the northern $\mathrm{Mo} \pm \mathrm{Cu}$ and middle $\mathrm{Sn} \pm$ $\mathrm{W} \pm \mathrm{Ag}$ mineralization belts come together (Figure 1b). The deposit represents an unusual example of Mo-polymetallic mineralization dominated by abundant $\mathrm{Mo}-\mathrm{Pb}-\mathrm{Zn}$ with minor $\mathrm{Ag}-\mathrm{Cu}$ mineralization. The polymetallic features of the Dongbulage deposit represent a change in the style of mineralization characteristics between the $\mathrm{Sn} \pm \mathrm{W} \pm \mathrm{Ag}$ and northern $\mathrm{Mo} \pm \mathrm{Cu}$ mineralization systems in this area.

The Dongbulage deposit shows a close spatial and genetic relationship with the enclosing granitic rocks, and displays a conspicuous feature of porphyry-epithermal ore-forming systems in which Mo orebodies are hosted within the subvolcanic rocks and adjacent breccia pipes, whereas the Ag-base metal orebodies are hosted in the contact zone between the subvolcanic rocks and host rocks. Based on fluid inclusion studies, $\mathrm{Li}$ et al. (2017) suggested that the ore-forming fluid is mainly derived from magmatic water [7]. However, the ages and petrogenesis of the ore-related magmatic rocks are still unclear, thus limits our understanding of the relationships between mineralization and magmatic activity.

Determining the age of porphyry magmatic-hydrothermal events is critical for understanding ore genesis and related geological processes. The most commonly used tools are $\mathrm{U}-\mathrm{Pb}$ zircon geochronology to date intrusive and high-temperature hydrothermal events, and Re-Os molybdenite geochronology to directly date sulfide mineralization stages. Combining the two techniques allows for clarification of the duration of magmatic-hydrothermal events associated with porphyry systems. In this manuscript, the genesis of the Dongbulage deposit is discussed based on the geology, petrology, and geochemistry of ore-related magmatic rocks, in conjunction with the molybdenite Re-Os ages of the ores and the zircon LA-ICP-MS U-Pb ages for the magmatic rocks. The aim of this study is to accurately constrain the ore-forming age, discuss the petrogenesis of the ore-related granites, and decipher ore genesis in the context of reconstructing the genetic evolution of porphyry systems and evaluating their duration.

\section{Geological Setting}

The Dongbulage Mo-polymetallic deposit is located in the southern part of the Great Xing'an Range, in a tectonic unit known as the eastern section of the $\mathrm{CAOB}$, which is often referred to as the Xing'an-Mongolian Orogenic Belt (XMOB) (Figure 1a) [8-11]. This region is considered to have experienced a complex geodynamic evolution under three distinct tectonic regimes: closure of the paleo-Asian Ocean during the Paleozoic, subduction and closure of the Mongol-Okhotsk Ocean during the Mesozoic, and subduction of the Pacific Plate during the Mesozoic-Cenozoic, which is associated with widespread magmatic and metamorphic events $[9,10]$.

During the Paleozoic, this area recorded the migration and final closure of the paleo-Asian Ocean between the China Craton (NCC) and the Siberian Craton (SC). The XMOB is interpreted to have consisted of Phanerozoic juvenile crust formed by the amalgamation of several blocks, including, from northwest to southeast, the Erguna (EB), Xing'an-Airgin Sum (XAB), Songliao-Hunshandake (SHB), and Jiamusi blocks (JB), separated by the Xinlin-Xiguitu (XXS), Xilinhot-Heihe (XHS), Mudanjiang (MS), and Ondor Sum-Yongji sutures (OYS) (Figure 1b) [10]. Although final closure time and tectonic evolution are still debated, the XMOB was a united continent by the Mesozoic [12-16]. Hence, there was a significant transition since the Mesozoic, with the tectonic development being controlled by the northwest (NW)-dipping subduction of the paleo-Pacific plate and the south (S) to southeast (SE)-dipping subduction of the Mongol-Okhotsk Ocean plate [9,17-22]. During this tectonic regime, a NE-trending stratigraphy and magmatism developed that controlled the location of variously aged strata and magmatic intrusions (Figure 1b,c). 


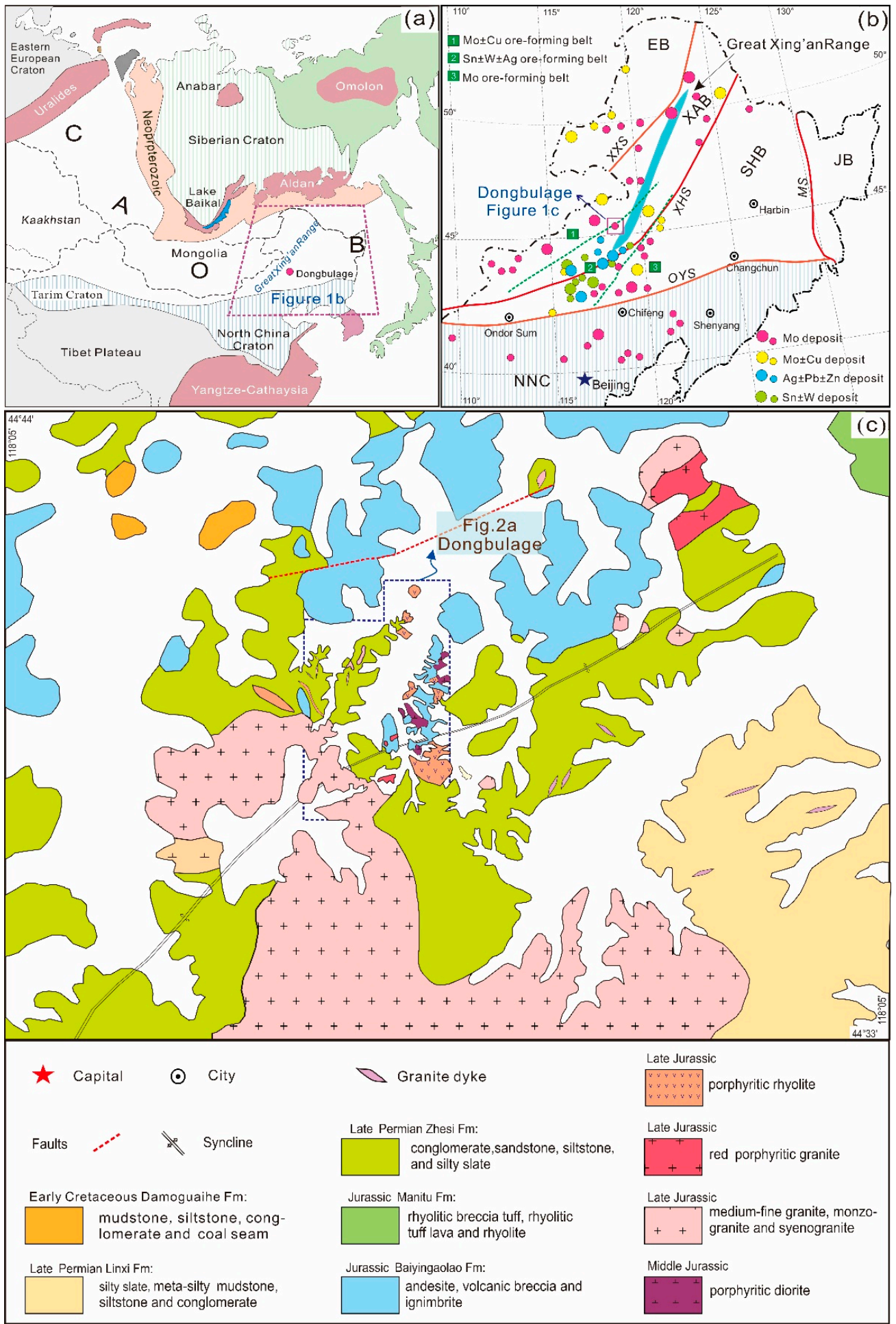

Figure 1. Geological maps: (a) location of the Central Asian Orogenic Belt (CAOB, modified after Jahn et al., 2000 [9]). (b) Map showing the regional tectonic framework of the Xing'an-Mongolian Orogenic Belt (XMOB, modified after Xu et al., 2015 [10]), NCC = North China Craton, EB = Erguna block, $\mathrm{XAB}=$ Xing'an-Airgin Sum block, SHB = Songliao-Hunshandake block, JB = Jiamusi block, XXS = Xinlin-Xiguitu Suture, $X H S=$ Xilinhot-Heihe Suture, MS = Mudanjiang Suture, OYS = Ondor Sum-Yongji Suture. The large and small circles in deposit type represent large and smaller base metal deposit, respectively. White areas show Quaternary rock. (c) Simplified regional geological map of the study area (modified after BGMRNMAR, 1991 [11]). White areas show Quaternary rock. 
The Dongbulage Mo-polymetallic deposit is located in the southeastern part of the XAB and the northern section of the deep-seated Erlian-Hougenshan Fault (Figure 1b). Two major tectonostratigraphic units have been recognized in the region: Permian sedimentary rocks and Jurassic-Cretaceous felsic volcano-sedimentary sequences (Figure 1c) [11,23]. The Permian sedimentary rocks show discontinuous upward facies change from shallow sea to terrestrial, and can be subdivided into the Zhesi and Linxi formations. They are unconformably overlain by Cretaceous lacustrine sedimentary rocks in the Damoguaihe Formation and Jurassic continental felsic volcanic rocks in the Manitu and Baiyingaolao formations (Figure 1c) [11].

Mesozoic granites are common in the region, and have intruded Permian sedimentary rocks and mid-Jurassic terrestrial volcano-sedimentary sequences (Figure 1c). According to the intrusive relationships (and our new ages), the Mesozoic granitoids in the region are mainly composed of Middle-Late Jurassic plutonic rocks and relatively young subvolcanic intrusive complexes. The plutonic rocks are mostly located in the southern part of region, and occur as batholith and stocks (Figure 1c). The plutonic rocks were considered to be a part of the Buerhaotu granitic batholith and were classified into fine-grained to medium-grained monzogranite and syenogranite (Figure 1c). At the northern marginal facies of the Buerhaotu granitic batholith, some rocks of the subvolcanic complex outcrop as dykes and small stocks, consisting mainly of porphyritic diorite, red porphyritic granite, and porphyritic rhyolite (Figures $1 \mathrm{c}$ and $2 \mathrm{a}$ ). It should be noted that many polymetallic hydrothermal deposits (e.g., large Baiyinnuoer $\mathrm{Pb}-\mathrm{Zn}-\mathrm{Ag}$, giant Shuangjianzishan $\mathrm{Ag}-\mathrm{Pb}-\mathrm{Zn}$, and large Haobugao $\mathrm{Fe}-\mathrm{Zn}-\mathrm{Cu}$, and Aonaodaba $\mathrm{Cu}-\mathrm{Sn}-\mathrm{Ag}$ deposits) are present in this region; these displays have a temporal and spatial relationship with the Mesozoic granites.

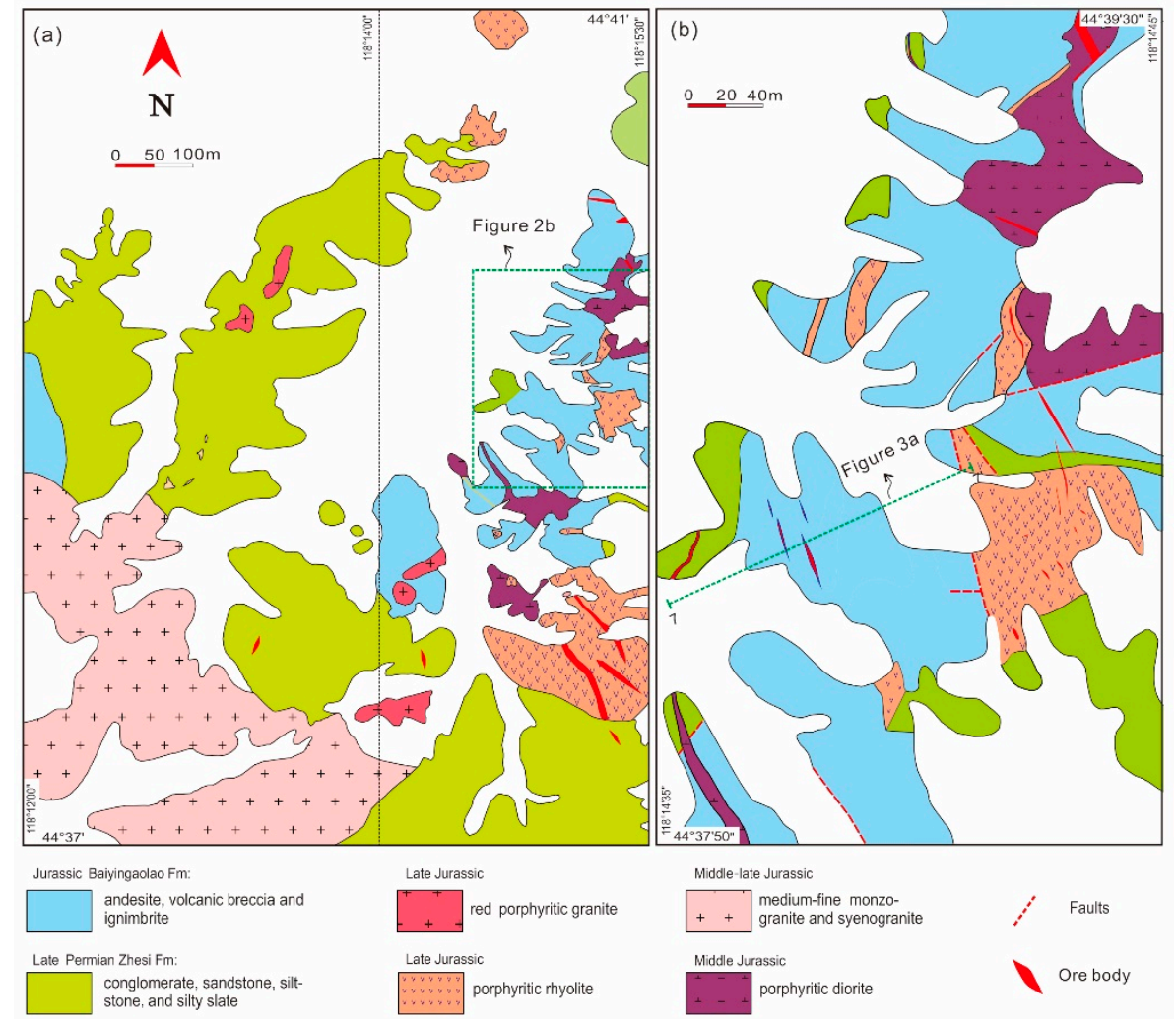

Figure 2. Geological maps of: (a) the Dongbulage ore district and (b) proximal Mo-bearing ore blocks in the mining exploration project area. White areas show quaternary (modified after ZXGE, 2010 [24]).

\section{Ore Deposit Geology}

The Dongbulage Mo-polymetallic deposit is located in the northern margin of the Buerhaotu granitic batholith and the axis of the NE-trending East Ujimqin Banner anticlinorium (Figures 1c and 2). 
The Mo-polymetallic mineralization occurs in a small area of approximately $1-2 \mathrm{~km}^{2}$, and is mainly hosted by the NNW, and roughly EW-trending faults and joints (Figures 2 and 3).

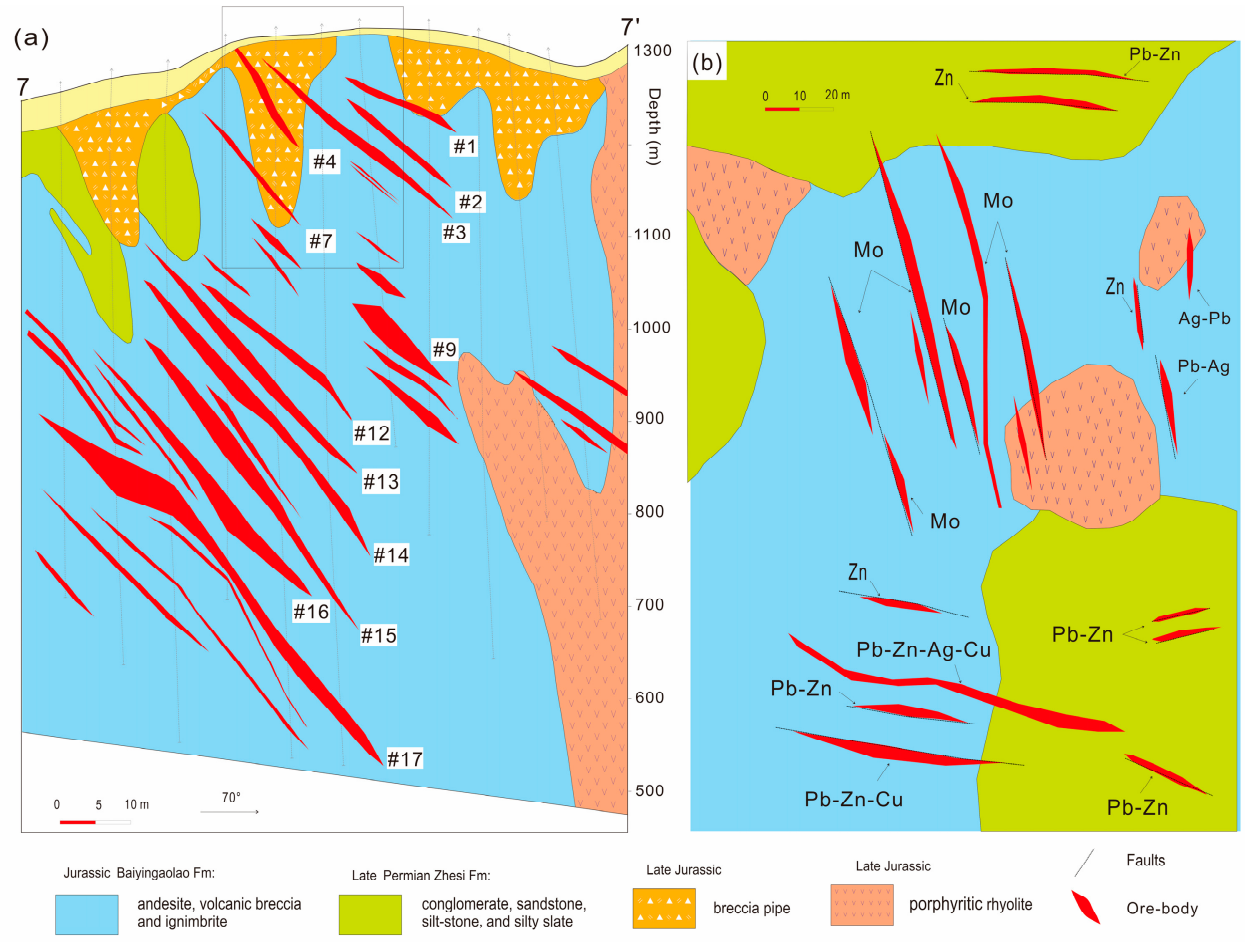

Figure 3. Diagrams showing: (a) simplified cross-section along No. 7 exploration line $\left(7-7^{\prime}\right)$ at Dongbulage showing the distribution of Mo orebodies, and the spatial relationship between orebodies and main host rocks (modified after ZXGE, 2010 [24]); (b) plan view of the Dongbulage deposit (1200 m above the see level) showing well-developed horizontal zoning outward from the subvolcanic stocks (modified after ZXGE, 2010 [24]).

\subsection{Host Rocks and Structures}

Host rocks at Dongbulage mainly consist of: (1) the NE-trending Late Permian Zhesi sedimentary succession (Figure 2a); (2) the Jurassic volcano-sedimentary sequences in the Baiyingaolao Formation and Porphyritic diorite (Figure 2a,b); (3) the Late Jurassic subvolcanic, together with the coeval concealed hydrothermal breccias (Figures 2 and $3 a$ ).

The major fractures and faults that developed in the inner and outer contact zones between the small stocks and adjacent host rocks are predominantly NNW-trending, and subordinately nearly EW-trending; these serve as major ore-controlling structures by providing conduits for the intrusion of magmatic rocks and the subsequent migration of the hydrothermal fluids that are responsible for mineralization (Figure 3).

\subsection{Mineralization and Zoning}

More than 100 orebodies had been outlined at Dongbulage by 2010, with 31 Mt of proved ore consisting of approximately $0.107 \% \mathrm{Mo}$, approximately $0.13 \% \mathrm{Zn}$, approximately $0.11 \% \mathrm{~Pb}$, approximately $0.19 \% \mathrm{Cu}$, and approximately $4.53 \mathrm{ppm} \mathrm{Ag} \mathrm{[24].} \mathrm{Three} \mathrm{types} \mathrm{of} \mathrm{mineralization} \mathrm{have}$ been recognized at Dongbulage. Disseminated and stockwork mineralization is mainly hosted by porphyritic rhyolite and adjacent country rock, the vein-type Mo-polymetallic mineralization is hosted by fractures and faults, and breccia mineralization occurs within cryptoexplosive breccia pipes. Of these, vein-type mineralization is the most abundant and economically important, and is essentially restricted to thick quartz-dominant veins ( $1 \mathrm{~m}$ in thickness), and small decimeter-scale (dm-scale) veins $(0.1-1 \mathrm{~m}$ thick) and veinlets (0.05-0.1 m thick) (Figure $4 \mathrm{a}, \mathrm{b})$. 

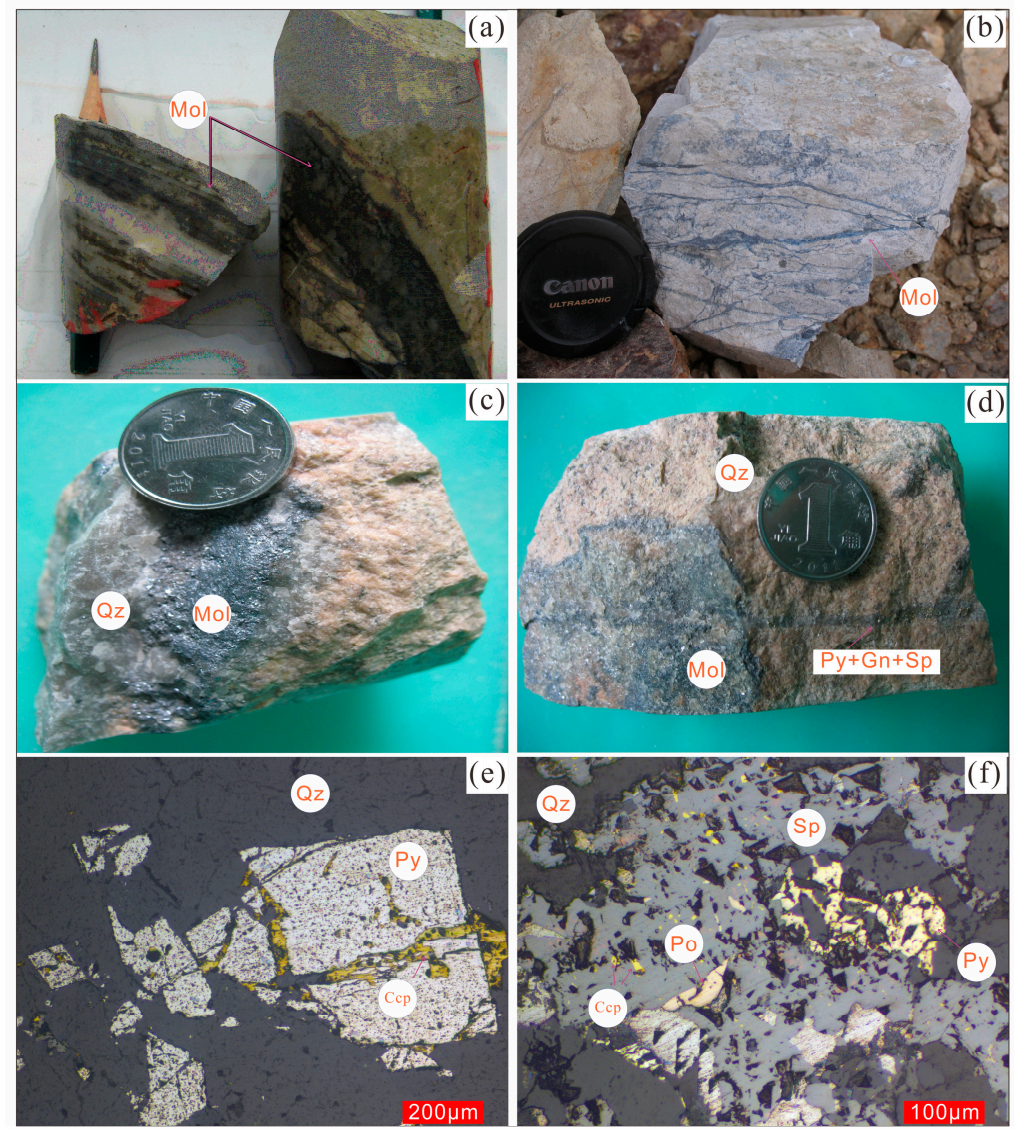

Figure 4. Photographs and photomicrographs of mineralization showing: (a) and (b) altered volcanic rocks with vein and veinlet molybdenite $(\mathrm{Mol})$; (c) and (d) altered porphyritic granite with crumby, flaked, and veinlet molybdenite (Mol); (e) irregularly-shaped pyrite (Py) with chalcopyrite (Ccp) in ore-bearing quartz vein (under reflected light); and (f) xenomorphic sphalerite (Sp), pyrite (Pyr), chalcopyrite (Ccp), and pyrrhotite (Po) intergrowths (under reflected light).

The mineralization shows well-developed horizontal zoning outward from the subvolcanic stocks. Based on metal assemblages, two main mineralized vein systems are recognized at Dongbulage: proximal Mo-bearing veins, which occur in the central part of the ore district, and distal $\mathrm{Zn} \pm \mathrm{Pb} \pm \mathrm{Cu}$ $\pm \mathrm{Ag}$ mineralization, which is found at the edge of the ore district (Figure $3 \mathrm{~b}$ ).

Mo mineralization is primarily restricted to the NNW-trending extensional faults and fractures that developed in the inner and the outer contact zones between small stocks and adjacent host rocks (Figure 3). Individual Mo orebodies are lens-shaped and vein-shaped. Lengths along the strike direction range from 20 to $650 \mathrm{~m}$, and vein widths range from 1.2 to $17 \mathrm{~m}$. Orebodies \#3, \#12, \#17 are the largest (Figure 3a). The Mo-bearing vein-type ores consist of quartz, subhedral pyrite $(<0.025 \mathrm{~mm}$ in size), and euhedral sheeted molybdenite (approximately $0.01-0.437 \mathrm{~mm}$ ), with associated muscovite, fluorite, and K-feldspar (Figure 4c,d). Bonanza horizons in the vein are lenticular in shape with a thickness of $<2 \mathrm{~m}$. The grade of bonanzas in this vein reaches $1.793 \%$, although the average grade is $0.107 \%$.

Distal $\mathrm{Zn} \pm \mathrm{Pb} \pm \mathrm{Cu} \pm \mathrm{Ag}$ mineralization is associated with shallow-level, nearly EW-trending faults and fractures within the Zhesi and Baiyingaolao formations (Figure 3b). The individual $\mathrm{Zn} \pm \mathrm{Pb}$ $\pm \mathrm{Cu} \pm \mathrm{Ag}$ orebodies are approximately 25 to $150 \mathrm{~m}$ in length, and approximately 1.03 to $9.80 \mathrm{~m}$ in thickness. The high concentrations of sulfides generally coincide with a high frequency of quartz veins. Economic $\mathrm{Zn} \pm \mathrm{Pb} \pm \mathrm{Cu} \pm \mathrm{Ag}$ vein-type mineralization mainly contains pyrite, sphalerite, and galena, with minor chalcopyrite, pyrrhotite, and argentite (Figure $4 \mathrm{e}, \mathrm{f})$. Gangue minerals are primarily quartz and K-feldspar, with minor amounts of chlorite, muscovite, fluorite, calcite, and kaolin. 


\subsection{Stages of Alterations and Ore Formation}

Alteration is well widespread within the ore-bearing porphyry and the contact host rocks, and is characterized by an early stage of K-silicate alteration at deeper levels of the mine, fracture-controlled silicification and sericite alteration, widespread propylitic alteration, and later argillic alteration [7]. According to the alteration-mineralization patterns and cross-cutting relationship of the veins, five stages of alteration-mineralization have been recognized: (1) the K-silicate stage; (2) the quartz + sericite + molybdenite stage; (3) the chlorite + sericite + sulfides stage; (4) the quartz + calcite stage; and (5) the anhydrite stage (Figure 5) [7].

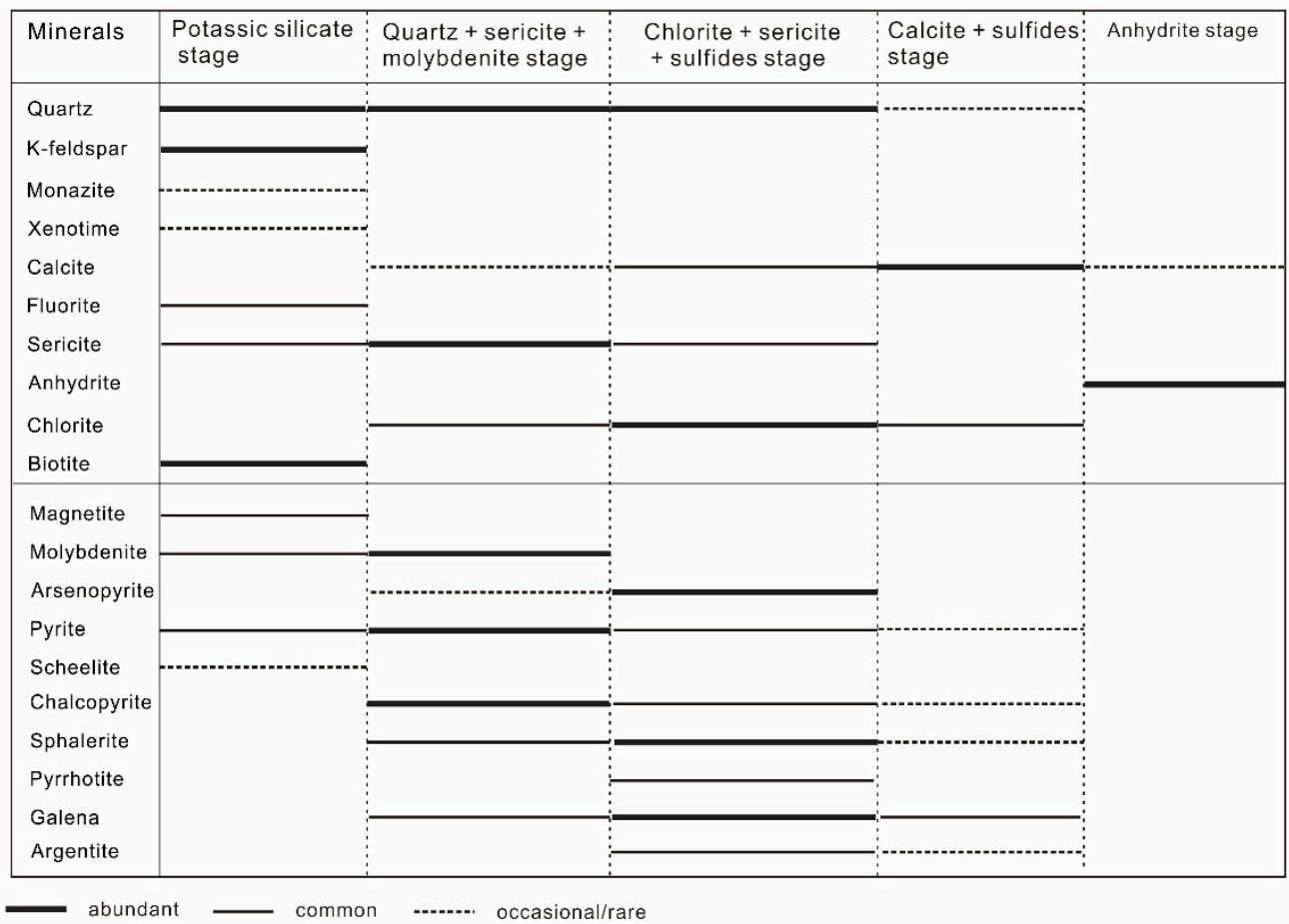

Figure 5. Mineral paragenesis of the Dongbulage Mo-polymetallic deposit (modified after Li et al., 2017 [7]).

The K-silicate stage represents the late magmatic and the initial hydrothermal stage, which is generally tightly confined to the volume occupied by deep porphyry stocks. Early K-silicate can be established, mainly consisting of quartz, K-feldspar, and biotite, with minor amounts of fluorite, pyrite, molybdenite, and magnetite, as well as traces of monazite, xenotime, and scheelite (Figure 5). During the K-silicate stage, K-feldspar and the biotite replacement of primary plagioclase in the porphyritic rhyolite is commonly observed. Moreover, in areas where the degree of K-silicate alteration is higher, disseminated and stockwork mineralization can be observed during this stage.

The quartz + sericite + molybdenite stage is the major alteration style associated with Mo mineralization, producing Mo-rich quartz veins hosted by NNW-trending faults and fractures. These veins are quite common in the porphyritic rhyolite and contact host rocks, and contain a medium-grained to coarse-grained quartz, sericite, calcite, and sulfide assemblage composed of chalcopyrite, pyrite, and molybdenite, with rare occurrences of euhedral arsenopyrite, sphalerite, and galena (Figure 5). Notably, economic vein-type Mo-mineralization occurs during this stage.

The chlorite + sericite + sulfides stage is third and the most important $\mathrm{Zn} \pm \mathrm{Pb} \pm \mathrm{Cu} \pm \mathrm{Ag}$ mineralizing event. It features veins controlled by the nearly EW-trending cracks and fault fractures developed primarily in the upper and outer parts of the porphyry stocks. The mineral assemblage in this stage is dominated by an intermediate-sulfidation combination composed of quartz + chlorite + muscovite + sphalerite + galena \pm chalcopyrite \pm arsenopyrite \pm argentite \pm argentite (Figure 5). 
The quartz + calcite stage is subeconomic and characterized by vein, veinlets, and the dissemination of quartz and calcite, as well as accessory amounts of sulfides (Figure 5). The anhydrite stage is the final phase, and exhibits fewer mineralized sulfides and cross and cutting minerals from earlier stages. It is represented by anhydrite veins and veinlets that are commonly approximately between $15-50 \mathrm{~mm}$ width (Figure 5).

\section{Sample Description and Analytical Methods}

A total of 12 whole-rock samples were systematically collected from major magmatic rocks for geochemical analyses. The samples mainly included monzogranite, syenogranite, red porphyritic granite, and porphyritic rhyolite. The petrographic characteristics of the samples are described below.

The monzogranite (YP08, 10, and 11) and syenogranite samples (YP23, 25, and 26) were collected from the Buerhaotu granitic batholith in the southern section of the Dongbulage ore district (Figure 1c). The monzogranite consists of approximately 0.2 to 5-mm K-feldspar (30-35 vol. \%), plagioclase (25-30 vol. \%), quartz (20 vol. \%), and biotite (5-10 vol. \%), with accessory amounts of magnetite, zircon, and apatite (Figure 6a). The syenogranite is composed of approximately 2 to 7-mm long phenocrysts (30-40 vol. \%) in an approximate 0.5 to 1-mm matrix (60-70 vol. \%). It consists of quartz ( 20 vol. $\%)$, plagioclase ( 25 vol. \%), K-feldspar ( 45 vol. \%), biotite ( 3 vol. \%), and accessory minerals ( 2 vol. \%), including zircon and fluorapatite (Figure $6 \mathrm{~b})$.
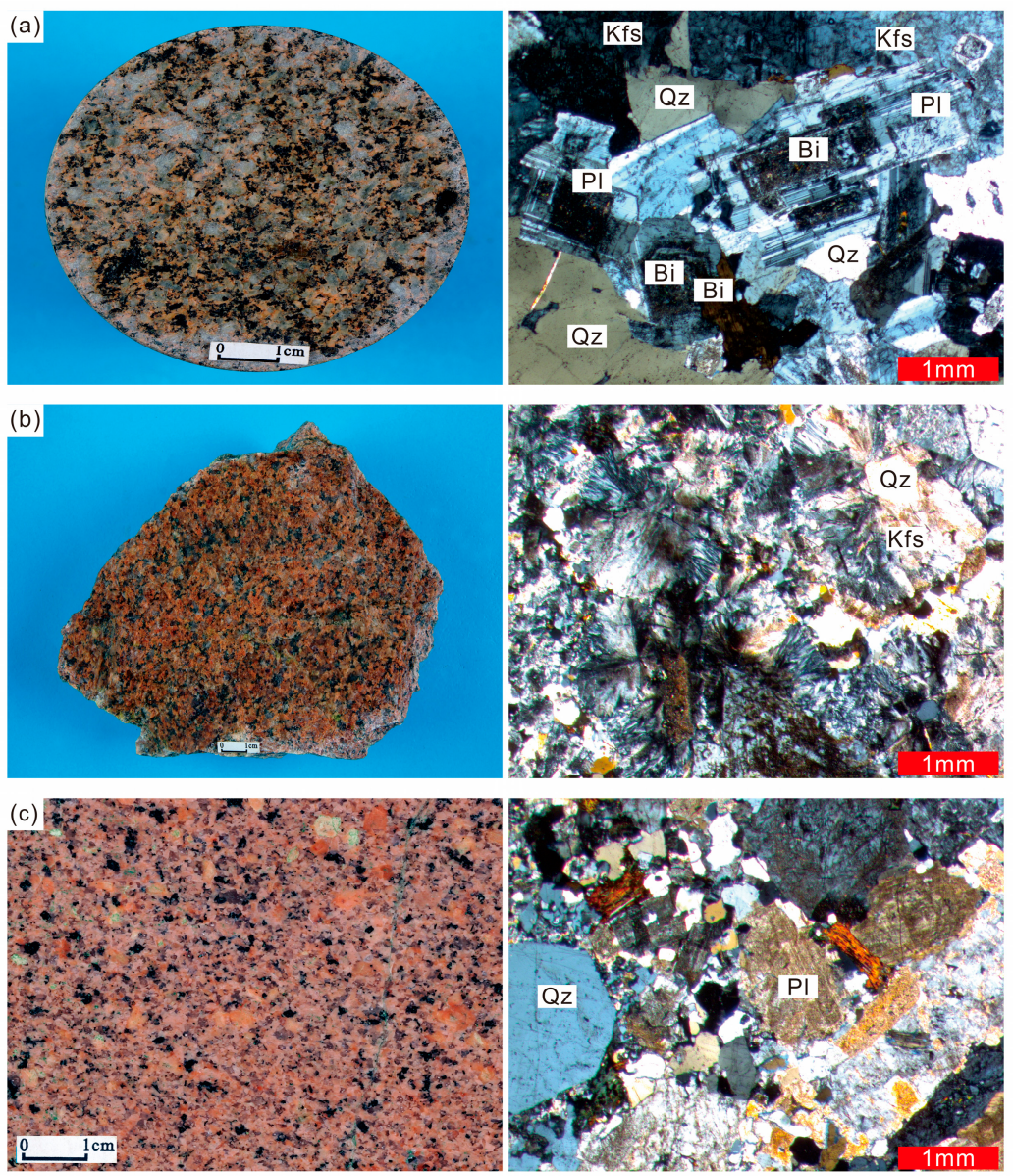

Figure 6. Cont. 

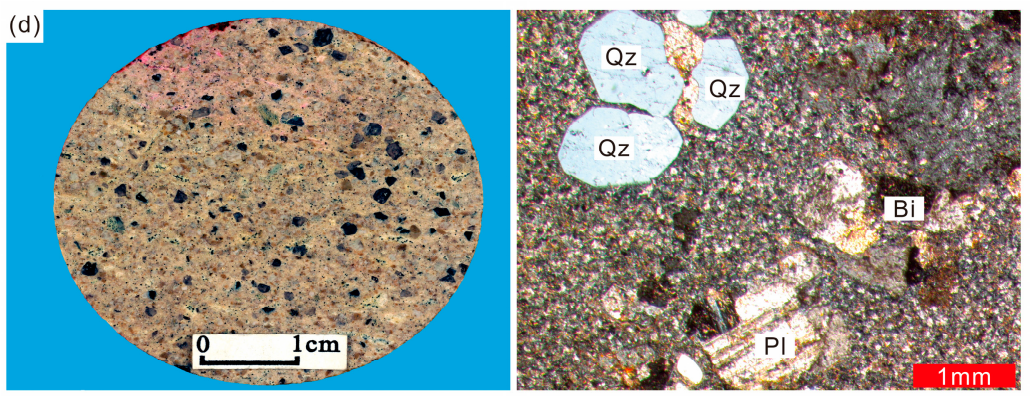

Figure 6. Representative microphotographs for intrusive rocks around Dongbulage: (a) monzogranite collected from Buerhaotu granitic batholith, mainly comprising plagioclase, quartz, K-feldspar, and biotite phenocrysts, and a felsic matrix with a microgranitic texture (under polarized light); (b) syenogranite collected from Buerhaotu granitic batholith, mainly consisting of K-feldspar, quartz phenocrysts, and felsic matrix (under polarized light), (c) red porphyritic granite collected from drill cores, light red in color, which contains quartz and K-feldspar phenocryst in a cryptocrystalline matrix (under polarized light), and (d) porphyritic rhyolite collected from drill cores, moderately porphyritic and rhotaxitic texture, and phenocrysts that are solely grayish quartz and altered potassium feldspar, and the matrix is hyalopilitic, comprising intertwined quartz and feldspar crystallites (under polarized light). Abbreviations: $\mathrm{Bi}=$ biotite, $\mathrm{Kfs}=\mathrm{K}$-feldspars, $\mathrm{Pl}=$ plagioclase, and $\mathrm{Qt}=$ quartz.

The samples of red porphyritic granite (YP32-34) and the samples of porphyritic rhyolite (YP6, 7, 11, and 28) were selected from drill cores at Dongbulage. Red porphyritic granite is light red in color and mainly contains quartz and K-feldspar phenocrysts (20-25 vol. \%) in a cryptocrystalline matrix (75-80 vol. \%), consisting of quartz, feldspar, and minor amounts of chlorite and zircon (Figure 6c). Porphyritic rhyolite is characterized by a moderately porphyritic texture, with phenocrysts (20 vol. \%) that are solely grayish quartz and altered potassium feldspar, and the matrix ( $80 \mathrm{vol} . \%)$ is hyalopilitic, mainly comprising intertwined quartz and feldspar crystallites (Figure 6d).

In order to constrain the ages of major magmatic rocks, whole-rock samples were selected for LA-ICP-MS zircon U-Pb dating. Furthermore, considering that the age for the mineralization is poorly constrained using Re-Os model ages, two samples of molybdenite were also collected from Dongbulage. The molybdenite in Sample YP-5 formed aggregates in the quartz vein, while the molybdenite in Sample YP-6 was disseminated and occurred in the Jurassic volcano-sedimentary sequences.

\subsection{Major and Trace Element Analyses}

A total of 12 whole-rock samples were crushed and powdered to less than 200 mesh size. Chemical analyses were performed at the National Research Center for Geoanalysis, Chinese Academy of Geological Sciences (CAGS), Beijing. Oxide concentrations were analyzed using a using an X-ray fluorescence spectrometer (Instrument model: PE 300D) with an analytical error of $<1.4 \%$, and trace elements were measured using an inductively coupled plasma mass spectrometry (ICP-MS). The analytical precision and accuracy of the analyses was better than $5 \%$ for the major elements and $10 \%$ for the trace elements. The analytical uncertainties are based on the US Geological Survey rock standards BCR-1 and AVG-2, and the Chinese national rock standard GSR-3 [4].

\subsection{LA-MC-ICP-MS Zircon U-Pb Dating}

Zircon grains were extracted from samples using density and magnetic separation techniques. Representative zircons were handpicked using a binocular microscope and photographed using orthogonal polarization, reflected light, and cathodoluminescence (CL) imaging. Approximately 24 grains were selected for $\mathrm{U}-\mathrm{Pb}$ isotope analyses, based on their morphology and internal structure. In situ zircon $\mathrm{U}-\mathrm{Pb}$ dating was completed using a Thermo Finnigan Neptune MC-ICP-MS instrument at the Key Laboratory of Crust-Mantle Materials and Environments, University of Science and Technology of China, Chinese Academy Sciences, Anhui Province, China. Laser ablation was performed using a 
New Wave UP 213 laser ablation system, with a laser ablation spot diameter of $32 \mu \mathrm{m}$. The carrier gas was He, and an external zircon standard $(91,500)$ was analyzed after five sample points. The NIST SRM610 standard was used for calibrating element concentrations. The operating conditions for the laser ablation system were provided by Liu et al. (2007) [25]. Since ${ }^{204} \mathrm{~Pb}$ could not be measured due to a low signal and interference from ${ }^{204} \mathrm{Hg}$ in the gas supply, a common lead correction was performed using the LaDating@Zrn Excel VBA program (Version 2, University of Oslo, Oslo, Norway) and Com $\mathrm{Pb}$ corr\#3_18 [26]. Errors for individual analyses by LA-ICP-MS are quoted at the $1 \sigma$ confidence level, while errors on pooled ages are quoted at the $95 \%(2 \sigma)$ level. Isoplot (ver. 3.0) was used to calculate the weighted mean ages and generate Concordia plots [27].

\subsection{Re-Os Dating}

Samples were crushed, separated, and handpicked using a binocular microscope to obtain non-oxidized molybdenite. Sample pretreatment and analysis were completed at the Re-Os Laboratory of the National Research Center of Geoanalysis, CAGS. The molybdenite samples were dissolved in an $\mathrm{HCl}-\mathrm{HNO}_{3}-\mathrm{H}_{2} \mathrm{O}$ solution in a Carius tube. Osmium was separated by distillation and rhenium was separated by extraction, as described by Du et al. $(1995,2001,2004)$ [28-30]. The Re and Os isotope ratios were determined using a TJA X-series ICP-MS manufactured by the Thermo Electron Corporation, Waltham, MA, USA. Shirey and Walker (1995), Stein et al. (1997), and Du et al. (2004) [30-32] describe the additional details of the analytical procedures used in this analysis. The ${ }^{187} \mathrm{Re} /{ }^{188} \mathrm{Os}$ and ${ }^{187} \mathrm{Os} /{ }^{188} \mathrm{Os}$ were calculated using the decay constant of ${ }^{187} \mathrm{Re}$, and $\lambda=$ equaled approximately $1.666 \times 10^{-11} \mathrm{a}^{-1}$, with an absolute uncertainty of approximately $0.017 \times 10^{-11}$ [33].

The uncertainty for the Re and Os contents was comprised of the weighting error for samples and diluent, the calibration error for the diluent, the fractionation correction error for mass measurements, and the measurement error of the isotopic ratio for the samples. The uncertainty for model ages consisted of the uncertainty of the decay constant. The Re-Os age uncertainties for the molybdenite analyses reported here are given as $2 \sigma$.

\section{Results}

\subsection{Whole-Rock Geochemistry}

Whole-rock geochemical data for the main magmatic rocks of Dongbulage are listed in Table 1. A brief summary is presented here. Before plotting, the assay results were normalized to $100 \%$ after accounting for the loss on ignition (LOI).

\subsubsection{Major Elements}

The samples of monzogranite and syenogranite selected from the Buerhaotu granitic batholith had a narrow range of $\mathrm{SiO}_{2}\left(65.09-66.22\right.$ wt. \% and 74.41-75.31 wt. \%), $\mathrm{Al}_{2} \mathrm{O}_{3}(15.99-16.78$ wt. \% and 12.79-13.10 wt. \%), $\mathrm{K}_{2} \mathrm{O}\left(3.22-4.22\right.$ wt. $\%$ and 3.62-4.48 wt. \%), and $\mathrm{Na}_{2} \mathrm{O}$ contents (4.96-5.62 wt. \% and 4.07-4.11 wt. \%), respectively. They are also characterized by high differentiation indices (DI; sum of normative $\mathrm{Q}+\mathrm{Or}+\mathrm{Ab}$ ) [34], ranging from 81.75 to 86.92 and 87.60 to 92.42, and high Rittman indices $\left[\sigma=\left(\mathrm{Na}_{2} \mathrm{O}+\mathrm{K}_{2} \mathrm{O}\right)^{2} /\left(\mathrm{SiO}_{2}-43\right)\right]$ (oxides in wt. \%), ranging from approximately 3.54 to 3.62 and approximately 1.98 to 2.30 , respectively (Table 1 ) [34,35]. On the $\mathrm{SiO}_{2}$ versus $\mathrm{K}_{2} \mathrm{O}+\mathrm{Na}_{2} \mathrm{O}$ diagram, the monzogranite samples plot in the quartz monzonite field, the syenogranite samples plot in the granite field (Figure 7a), and all the samples fall within the high-K calc-alkaline series of granitic rocks (Figure $7 \mathrm{~b}$ ). On the $\mathrm{A} / \mathrm{CNK}\left[\mathrm{A} / \mathrm{CNK}=\mathrm{Al}_{2} \mathrm{O}_{3} /\left(\mathrm{CaO}+\mathrm{Na}_{2} \mathrm{O}+\mathrm{K}_{2} \mathrm{O}\right)(\right.$ molar ratio)] versus $\mathrm{A} / \mathrm{NK}$ $\left[\mathrm{A} / \mathrm{NK}=\mathrm{Al}_{2} \mathrm{O}_{3} /\left(\mathrm{Na}_{2} \mathrm{O}+\mathrm{K}_{2} \mathrm{O}\right)\right.$ (molar ratio) $]$ diagram, the monzogranite samples are moderately peraluminous, with $\mathrm{A} / \mathrm{CNK}$ values of approximately 1.02 to 1.06 , and all the syenogranite samples fall within the metaluminous peraluminous transitional field (Figure 7c). One notable feature is that monzogranite and syenogranite both have low ratios of $\left[\mathrm{Fe}_{2} \mathrm{O}_{3} /\left(\mathrm{Fe}_{2} \mathrm{O}_{3}+\mathrm{FeO}\right)\right](0.19$ to 0.27 and 0.26 to 0.37, respectively), suggesting that all are reduced intrusions $(<0.4)$ [36]. 
Table 1. Major and trace elements compositions for the rocks in the Dongbulage Mo-polymetallic deposit.

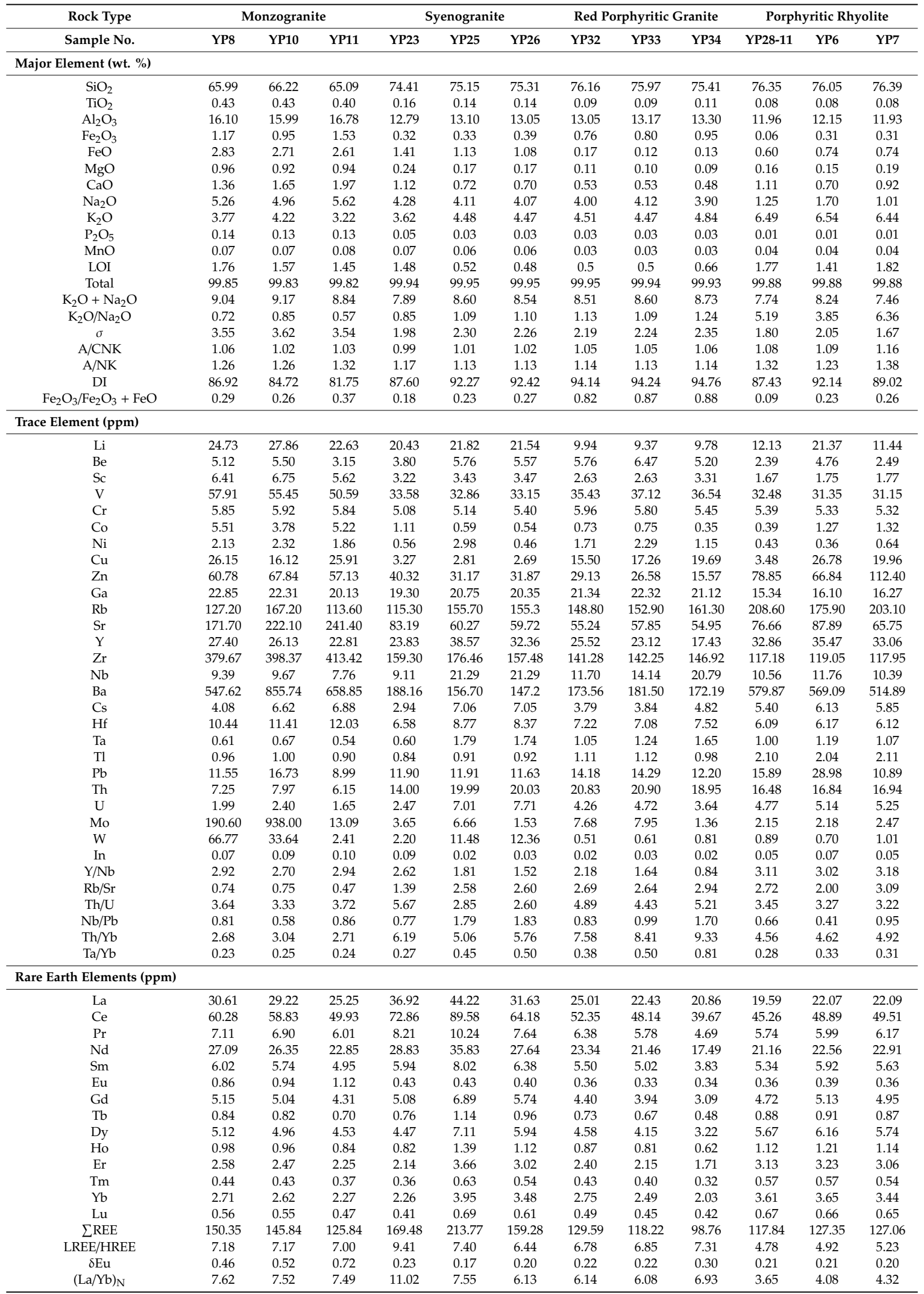

Notes: LOI is loss on ignition; TREE, total rare earth elements; LREE, light rare earth elements; HREE, heavy rare earth elements. $\mathrm{A} / \mathrm{CNK}=\mathrm{Al}_{2} \mathrm{O}_{3} /\left(\mathrm{CaO}+\mathrm{Na}_{2} \mathrm{O}+\mathrm{K}_{2} \mathrm{O}\right)\left(\right.$ molar ratio), $\mathrm{A} / \mathrm{NK}=\mathrm{Al}_{2} \mathrm{O}_{3} /\left(\mathrm{Na}_{2} \mathrm{O}+\mathrm{K}_{2} \mathrm{O}\right)$ (molar ratio), $\mathrm{DI}$ $=$ sum of normative $\mathrm{Q}+\mathrm{Or}+\mathrm{Ab}[34],(\mathrm{La} / \mathrm{Yb})_{\mathrm{N}}=\left(\mathrm{La} / \mathrm{La}^{*}\right) /\left(\mathrm{Yb} / \mathrm{Yb}{ }^{*}\right) ; \delta \mathrm{Eu}=\left(\mathrm{Eu} / \mathrm{Eu}^{*}\right) /\left\{0.5 \times\left[\left(\mathrm{Sm} / \mathrm{Sm}^{*}\right)+\left(\mathrm{Gd} / \mathrm{Gd}^{*}\right)\right]\right\}$; $\sigma($ The Rittmann Index $)=\left(\mathrm{Na}_{2} \mathrm{O}+\mathrm{K}_{2} \mathrm{O}\right)_{2} /\left(\mathrm{SiO}_{2}-43\right)$ (the oxide in wt. \%); $(\mathrm{La} / \mathrm{Yb})_{\mathrm{N}}$ is normalized using values. Several rare earths are shown as chondrite-normalized using values from [35]. 

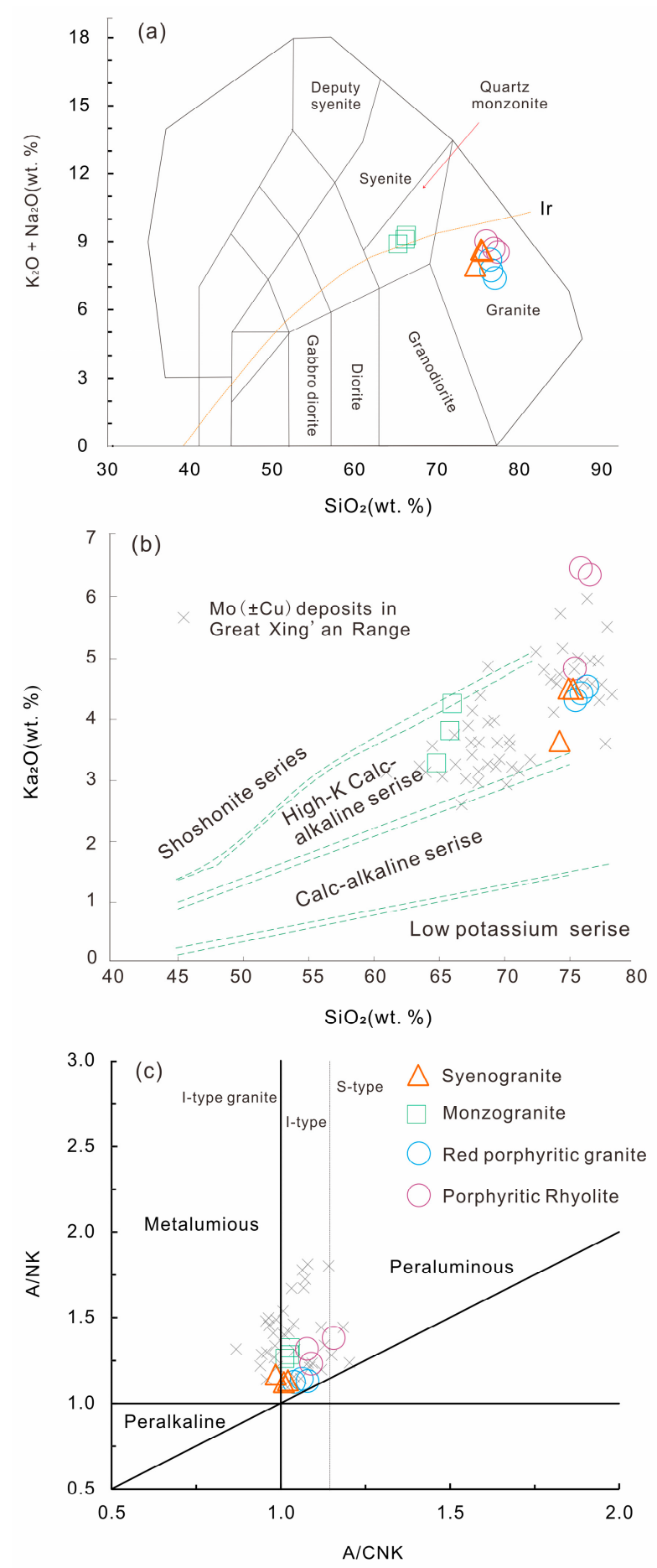

Figure 7. Geochemical plots for samples from Dongbulage of: (a) total alkali versus silica [37], (b) $\mathrm{SiO}_{2}$ versus $\mathrm{K}_{2} \mathrm{O}$, and (c) $\mathrm{A} / \mathrm{CNK}$ versus $\mathrm{A} / \mathrm{NK}$ [38].

Compared to the plutons (monzogranite and syenogranite), the red porphyritic granites showed highly evolved features, with $\mathrm{SiO}_{2}$ contents ranging from approximately 75.41 to $76.16 \mathrm{wt}$. \% and DI values ranging between 94.14-94.76 (Table 1). The samples from the porphyritic rhyolite also exhibited high felsic compositions, with $\mathrm{SiO}_{2}$ contents ranging between $76.05-76.39 \mathrm{wt}$. \% and DI ranging between 87.43-92.14. Both red porphyritic granite and porphyritic rhyolite had high concentrations of total alkalis (8.51-8.73 wt. \% and 7.46-8.24 wt. \%, respectively) as well as $\mathrm{Al}_{2} \mathrm{O}_{3}(13.05-13.30 \mathrm{wt}$. \% and 15.9-16.78 wt. \%), with Rittman indices between 2.19-2.35 and 1.67-2.05, respectively (Table 1). 
On the $\mathrm{SiO}_{2}$ versus $\mathrm{K}_{2} \mathrm{O}+\mathrm{Na}_{2} \mathrm{O}$ diagram, all the samples from porphyritic granite and rhyolite plot in the granite field (Figure 7a) are weak peraluminous, with A/CNK ratios of 1.05-1.16, and belong to the high-K calc-alkaline series of granitic rocks (Figure $7 \mathrm{~b}, \mathrm{c}$ ). Although samples of rhyolitic and granitic porphyry have similar major compositions, they differ in $\left[\mathrm{Fe}_{2} \mathrm{O}_{3} /\left(\mathrm{Fe}_{2} \mathrm{O}_{3}+\mathrm{FeO}\right)\right]$ values. Samples from porphyritic rhyolite are more oxidized than samples of granitic porphyry [36].

\subsubsection{Trace Elements}

Chondrite normalized rare earth element (REE) patterns for monzogranite, syenogranite, porphyritic rhyolite, and porphyritic granite were roughly similar; they show high levels contents of total rare earth elements ( $\sum$ REE) and are enriched in light rare earth elements (LREEs), and depleted in heavy rare earth elements (HREEs), with negative $\mathrm{Eu} / \mathrm{Eu}^{*}(\delta \mathrm{Eu})$ compared to common magmatic rocks (Table 1 and Figure 8a) [39]. Specifically, all the samples contained high levels of total rare earth

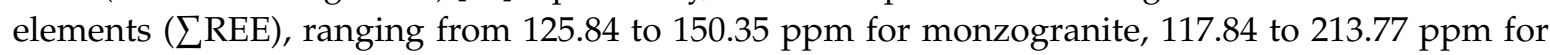
syenogranite, 98.76 to $129.59 \mathrm{ppm}$ for granitic porphyry, and 117.84 to $127.35 \mathrm{ppm}$ for porphyritic rhyolite. Monzogranite exhibited negative $\delta$ Eu values between $0.46-0.72$, LREE/HREE values between 6.44-9.41, and $(\mathrm{La} / \mathrm{Yb})_{\mathrm{N}}$ values between 7.49-7.62 (Table 1), whereas syenogranite yielded moderately negative $\delta$ Eu values of approximately 0.17 to 0.23 , LREE/HREE values of approximately 6.13 to 11.02 , and $(\mathrm{La} / \mathrm{Yb})_{\mathrm{N}}$ values of approximately 7.00 to 7.18 (Table 1). Compared with pluton, porphyritic rhyolite and porphyritic granite both record negative $\delta$ Eu values between $0.20-0.21$ and $0.22-0.30$, LREE/HREE values between 4.78-5.23 and 6.78-7.31, and $(\mathrm{La} / \mathrm{Yb})_{\mathrm{N}}$ values between 3.65-4.32 and approximately 6.08-6.93, respectively (Table 1).

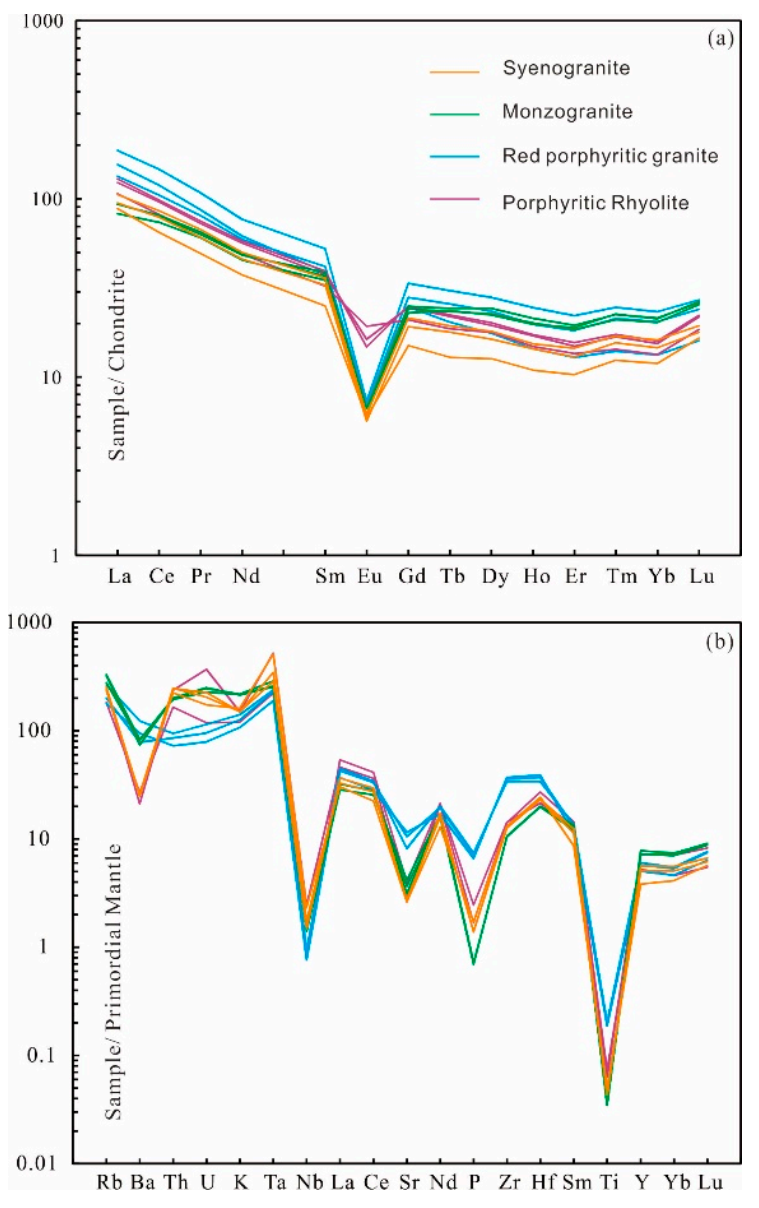

Figure 8. Geochemical plots for samples from Dongbulage of (a) chondrite-normalized rare earth element (REE) patterns; and (b) primitive-mantle normalized spider diagram (chondrite and primitive mantle values are from $[35,39])$. 
The primitive mantle normalized spider diagram indicates that the trace element characteristics for all the samples had broadly similar patterns, with elevated large-ion lithophile elements (LILE, such as $\mathrm{U}, \mathrm{K}, \mathrm{Rb}$, and $\mathrm{Hf}$ ) and depleted high field strength elements (HFSE, such as $\mathrm{Nb}$ and $\mathrm{Ta}$ ) (Figure 8).

\subsection{Zircon $\mathrm{U}-\mathrm{Pb}$ Dating}

Zircons extracted from the main magmatic rocks at Dongbulage are a light to dark brown color, transparent, and dominated by typically short-prismatic, long-prismatic, and equigranular shapes, with width-to-length ratios of approximately 1:3.7 (Figure 9). All the zircon grains analyzed have a well-preserved oscillatory zoning indicative of a magmatic origin (Figure 9). Zircon ${ }^{206} \mathrm{~Pb} /{ }^{238} \mathrm{U}$ ages for the main magmatic rocks have been summarized in Table 2 and are displayed in Figure 10.

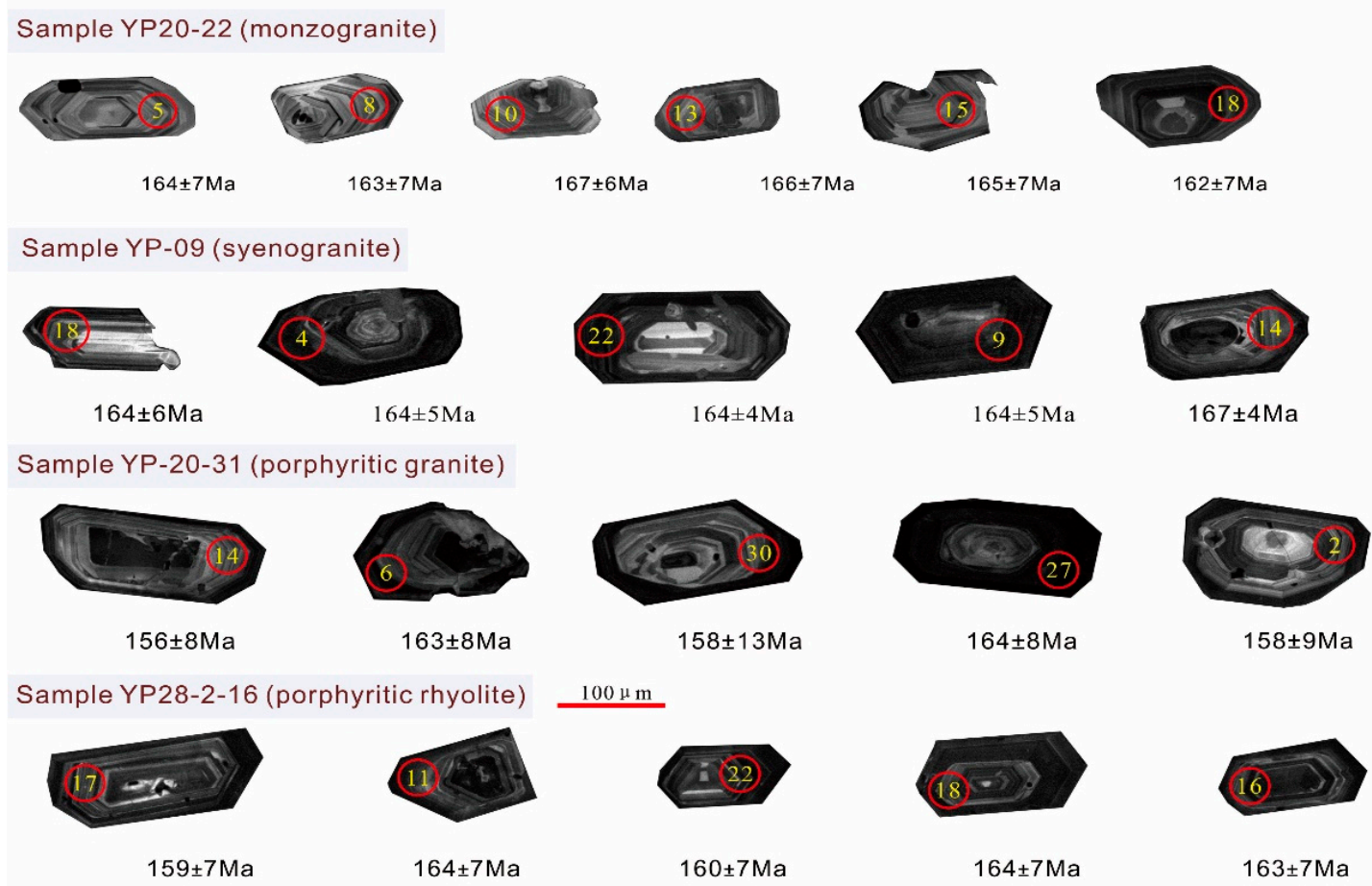

Figure 9. Representative cathodoluminescence (CL) images of zircons from samples. Note: the numbers in circles are test points.

A total of 24 zircon grains extracted from Sample YP20-22 (monzogranite) are analyzed, and they exhibit a wide range of ${ }^{232} \mathrm{Th}$ (55.39 to $1333.6 \mathrm{ppm}$ ) and ${ }^{238} \mathrm{U}$ (90.89 to $2288.74 \mathrm{ppm}$ ) concentrations and associated Th/U ratios of approximately 0.45 to 1.36 (Table 2). Seventeen zircon analyses yielded concordant ${ }^{206} \mathrm{~Pb} /{ }^{238} \mathrm{U}$ dates ranging from $168 \pm 6$ to $159 \pm 6 \mathrm{Ma}$, with a weighted mean date of $165 \pm 3$ Ma [MSWD (mean square of weighted deviates) $=0.13$ ]; Table 2 and Figure 10a,b). This mean date was interpreted to be the crystallization age for the fine-grained to medium-grained monzogranite. Five points were not concordant and were excluded from the age calculation. 
Table 2. LA-MC-ICP-MS zircon U-Pb data for samples from the Dongbulage Mo-polymetallic deposit. ICP-MS: inductively coupled plasma mass spectrometry.

\begin{tabular}{|c|c|c|c|c|c|c|c|c|c|c|c|c|c|c|c|c|}
\hline \multirow{2}{*}{ Spot \# } & \multirow[t]{2}{*}{ Total Pb } & \multirow{2}{*}{$\begin{array}{l}{ }^{232} \mathrm{Th} \\
10^{-6}\end{array}$} & \multirow[t]{2}{*}{${ }^{238} \mathrm{U}$} & \multirow{2}{*}{${ }^{232} \mathrm{Th} /{ }^{238} \mathrm{U}$} & \multicolumn{6}{|c|}{ Corrected Isotopic Ratios } & \multicolumn{6}{|c|}{ Corrected Age (Ma) } \\
\hline & & & & & ${ }^{207} \mathrm{~Pb} /{ }^{206} \mathrm{~Pb}$ & $\pm 1 \sigma$ & ${ }^{207} \mathrm{~Pb} /{ }^{235} \mathrm{U}$ & $\pm 1 \sigma$ & ${ }^{206} \mathrm{~Pb} /{ }^{238} \mathrm{U}$ & $\pm 1 \sigma$ & ${ }^{207} \mathrm{~Pb} /{ }^{206} \mathrm{~Pb}$ & $\pm 1 \sigma$ & ${ }^{207} \mathrm{~Pb} /{ }^{235} \mathrm{U}$ & $\pm 1 \sigma$ & ${ }^{206} \mathrm{~Pb} /{ }^{238} \mathrm{U}$ & $\pm 1 \sigma$ \\
\hline \multicolumn{17}{|l|}{ YP20-22 } \\
\hline 1 & 35.36 & 1241.6 & 934.87 & 1.33 & 0.04997 & 0.00248 & 0.17851 & 0.01084 & 0.02591 & 0.00092 & 194 & 116 & 167 & 9 & 165 & 6 \\
\hline 4 & 18.59 & 467.34 & 542.68 & 0.86 & 0.05754 & 0.0033 & 0.20656 & 0.01375 & 0.02603 & 0.00098 & 512 & 129 & 191 & 12 & 166 & 6 \\
\hline 5 & 20.53 & 523.71 & 570.89 & 0.92 & 0.04754 & 0.00326 & 0.17177 & 0.01302 & 0.0262 & 0.00099 & 77 & 152 & 161 & 11 & 167 & 6 \\
\hline 7 & 7 & 136.57 & 221.77 & 0.62 & 0.05163 & 0.00499 & 0.18198 & 0.01813 & 0.02556 & 0.00104 & 269 & 206 & 170 & 16 & 163 & 7 \\
\hline 9 & 72.07 & 1029.7 & 2288.74 & 0.45 & 0.04879 & 0.0011 & 0.17701 & 0.0072 & 0.02631 & 0.00089 & 138 & 50 & 165 & 6 & 167 & 6 \\
\hline 10 & 11.48 & 264.61 & 338.01 & 0.78 & 0.05195 & 0.00233 & 0.18758 & 0.01086 & 0.02619 & 0.00094 & 283 & 97 & 175 & 9 & 167 & 6 \\
\hline 12 & 6.2 & 113.71 & 192.55 & 0.59 & 0.05287 & 0.00385 & 0.19272 & 0.0156 & 0.02644 & 0.00102 & 323 & 161 & 179 & 13 & 168 & 6 \\
\hline 14 & 5 & 95.3 & 156.4 & 0.61 & 0.05552 & 0.00534 & 0.19687 & 0.01958 & 0.02572 & 0.00114 & 433 & 214 & 182 & 17 & 164 & 7 \\
\hline 16 & 6.38 & 136.99 & 201.09 & 0.68 & 0.05408 & 0.00602 & 0.18987 & 0.02098 & 0.02547 & 0.00112 & 374 & 237 & 177 & 18 & 162 & 7 \\
\hline 17 & 8.46 & 233.86 & 257.07 & 0.91 & 0.04793 & 0.00307 & 0.16496 & 0.01193 & 0.02496 & 0.00092 & 96 & 137 & 155 & 10 & 159 & 6 \\
\hline 18 & 5.82 & 104.26 & 184.02 & 0.57 & 0.05829 & 0.00565 & 0.20832 & 0.02044 & 0.02592 & 0.00105 & 541 & 213 & 192 & 17 & 165 & 7 \\
\hline 19 & 7.27 & 183.33 & 213.82 & 0.86 & 0.04694 & 0.00367 & 0.16938 & 0.01413 & 0.02617 & 0.00101 & 46 & 168 & 159 & 12 & 167 & 6 \\
\hline 20 & 3.22 & 55.39 & 102.65 & 0.54 & 0.04375 & 0.00459 & 0.15631 & 0.01695 & 0.02591 & 0.00116 & -84 & 186 & 147 & 15 & 165 & 7 \\
\hline 21 & 4.54 & 123.73 & 134.75 & 0.92 & 0.04973 & 0.00459 & 0.17623 & 0.01647 & 0.0257 & 0.00106 & 182 & 210 & 165 & 14 & 164 & 7 \\
\hline 22 & 2.83 & 44.46 & 90.89 & 0.49 & 0.06012 & 0.00673 & 0.21371 & 0.02427 & 0.02578 & 0.00117 & 608 & 257 & 197 & 20 & 164 & 7 \\
\hline 23 & 36.52 & 1333.6 & 980.7 & 1.36 & 0.05274 & 0.00233 & 0.1862 & 0.01028 & 0.0256 & 0.00094 & 318 & 103 & 173 & 9 & 163 & 6 \\
\hline 24 & 7.36 & 193.43 & 212.5 & 0.91 & 0.05433 & 0.00397 & 0.19344 & 0.01552 & 0.02582 & 0.00096 & 385 & 170 & 180 & 13 & 164 & 6 \\
\hline \multicolumn{17}{|l|}{ YP-09 } \\
\hline 2 & 8.89 & 261.72 & 250.22 & 1.05 & 0.04383 & 0.00413 & 0.15543 & 0.01483 & 0.02572 & 0.00087 & 82 & 102 & 158 & 7 & 163 & 5 \\
\hline 3 & 35.94 & 498.95 & 1181.54 & 0.42 & 0.04766 & 0.00222 & 0.1682 & 0.00847 & 0.0256 & 0.00074 & 52 & 93 & 157 & 7 & 164 & 5 \\
\hline 4 & 43.48 & 613.45 & 1435.61 & 0.43 & 0.04705 & 0.00204 & 0.16666 & 0.00793 & 0.02569 & 0.00077 & 283 & 153 & 169 & 11 & 161 & 5 \\
\hline 5 & 13.72 & 264.63 & 436.01 & 0.61 & 0.05194 & 0.00356 & 0.18088 & 0.0124 & 0.02525 & 0.0008 & 308 & 134 & 173 & 10 & 164 & 5 \\
\hline 6 & 17.92 & 238.3 & 598.49 & 0.40 & 0.05251 & 0.00315 & 0.18612 & 0.01164 & 0.02571 & 0.0008 & 814 & 304 & 212 & 26 & 161 & 6 \\
\hline 7 & 5.62 & 194.09 & 144.2 & 1.35 & 0.06625 & 0.00941 & 0.23171 & 0.03203 & 0.02537 & 0.00101 & 521 & 178 & 194 & 15 & 168 & 6 \\
\hline 8 & 21.84 & 283.93 & 689.22 & 0.41 & 0.05777 & 0.00478 & 0.21039 & 0.01745 & 0.02641 & 0.00088 & 170 & 99 & 164 & 7 & 164 & 5 \\
\hline 10 & 4.25 & 76.4 & 136.88 & 0.56 & 0.03812 & 0.00625 & 0.13929 & 0.02229 & 0.0265 & 0.00112 & 763 & 126 & 207 & 11 & 162 & 5 \\
\hline 11 & 14.33 & 347.12 & 420.49 & 0.83 & 0.06464 & 0.00398 & 0.22618 & 0.01352 & 0.02538 & 0.00073 & 338 & 94 & 176 & 8 & 164 & 4 \\
\hline 12 & 30.72 & 818.64 & 888.25 & 0.92 & 0.05321 & 0.00243 & 0.18907 & 0.00949 & 0.02577 & 0.00071 & 474 & 163 & 185 & 13 & 163 & 5 \\
\hline 13 & 8.44 & 251.76 & 237.23 & 1.06 & 0.05656 & 0.0046 & 0.20007 & 0.01549 & 0.02566 & 0.00084 & 338 & 89 & 179 & 7 & 167 & 4 \\
\hline 14 & 37.59 & 1135.9 & 1054.6 & 1.08 & 0.05322 & 0.0023 & 0.19291 & 0.00861 & 0.02629 & 0.00071 & 208 & 77 & 166 & 6 & 163 & 4 \\
\hline 15 & 62.59 & 945.5 & 2061.53 & 0.46 & 0.05029 & 0.00185 & 0.17798 & 0.00731 & 0.02567 & 0.0007 & 205 & 120 & 164 & 10 & 161 & 5 \\
\hline 16 & 35.2 & 831.24 & 1088.36 & 0.76 & 0.05021 & 0.00291 & 0.17558 & 0.01178 & 0.02536 & 0.00083 & 136 & 166 & 164 & 12 & 166 & 5 \\
\hline 17 & 22.5 & 306.95 & 704.98 & 0.44 & 0.04876 & 0.00405 & 0.17578 & 0.01406 & 0.02615 & 0.00086 & 427 & 129 & 182 & 11 & 164 & 6 \\
\hline 18 & 11.62 & 298.73 & 338.83 & 0.88 & 0.05536 & 0.00355 & 0.19635 & 0.01329 & 0.02572 & 0.00092 & 424 & 201 & 182 & 17 & 164 & 7 \\
\hline 19 & 6.4 & 89.64 & 211.38 & 0.42 & 0.0553 & 0.00557 & 0.19634 & 0.01961 & 0.02575 & 0.00119 & 508 & 173 & 187 & 15 & 163 & 6 \\
\hline 21 & 16.67 & 604.9 & 448.85 & 1.35 & 0.04256 & 0.00312 & 0.14943 & 0.01073 & 0.02547 & 0.00079 & 238 & 114 & 168 & 8 & 164 & 4 \\
\hline 22 & 24.67 & 776.52 & 692.41 & 1.12 & 0.05095 & 0.00268 & 0.18048 & 0.00954 & 0.02569 & 0.0007 & 315 & 104 & 174 & 8 & 164 & 4 \\
\hline
\end{tabular}


Table 2. Cont

\begin{tabular}{|c|c|c|c|c|c|c|c|c|c|c|c|c|c|c|c|c|}
\hline \multirow{2}{*}{ Spot\# } & \multirow[t]{2}{*}{ Total Pb } & \multirow{2}{*}{$\begin{array}{l}{ }^{232} \mathrm{Th} \\
10^{-6}\end{array}$} & \multirow[t]{2}{*}{${ }^{238} \mathrm{U}$} & \multirow{2}{*}{${ }^{232} \mathrm{Th} /{ }^{238} \mathrm{U}$} & \multicolumn{6}{|c|}{ Corrected Isotopic Ratios } & \multicolumn{6}{|c|}{ Corrected Age (Ma) } \\
\hline & & & & & ${ }^{207} \mathrm{~Pb} /{ }^{206} \mathrm{~Pb}$ & $\pm 1 \sigma$ & ${ }^{207} \mathrm{~Pb} /{ }^{235} \mathrm{U}$ & $\pm 1 \sigma$ & ${ }^{206} \mathrm{~Pb} /{ }^{238} \mathrm{U}$ & $\pm 1 \sigma$ & ${ }^{207} \mathrm{~Pb} /{ }^{206} \mathrm{~Pb}$ & $\pm 1 \sigma$ & ${ }^{207} \mathrm{~Pb} /{ }^{235} \mathrm{U}$ & $\pm 1 \sigma$ & ${ }^{206} \mathrm{~Pb} /{ }^{238} \mathrm{U}$ & $\pm 1 \sigma$ \\
\hline \multicolumn{17}{|l|}{ YP20-31 } \\
\hline 1 & 6.08 & 151.88 & 185.24 & 0.82 & 0.04357 & 0.00524 & 0.15557 & 0.01995 & 0.0259 & 0.00139 & -93 & 191 & 147 & 18 & 165 & 6 \\
\hline 2 & 11.68 & 494.06 & 299.72 & 1.65 & 0.04676 & 0.00586 & 0.1598 & 0.02066 & 0.02479 & 0.00142 & 37 & 231 & 151 & 18 & 158 & 6 \\
\hline 4 & 14.09 & 227.63 & 469.44 & 0.48 & 0.05042 & 0.00352 & 0.17477 & 0.01468 & 0.02514 & 0.00126 & 214 & 153 & 164 & 13 & 160 & 8 \\
\hline 7 & 13.43 & 388.05 & 413.16 & 0.94 & 0.05889 & 0.00421 & 0.20129 & 0.01757 & 0.02479 & 0.00127 & 563 & 154 & 186 & 15 & 158 & 6 \\
\hline 9 & 30.32 & 394.77 & 1018.82 & 0.39 & 0.05549 & 0.00343 & 0.19611 & 0.01455 & 0.02563 & 0.00124 & 432 & 129 & 182 & 12 & 163 & 8 \\
\hline 10 & 8.1 & 262.99 & 226.44 & 1.16 & 0.04746 & 0.00454 & 0.16428 & 0.01673 & 0.0251 & 0.0013 & 72 & 195 & 154 & 15 & 160 & 4 \\
\hline 11 & 22.04 & 266.6 & 724.72 & 0.37 & 0.04884 & 0.00238 & 0.17788 & 0.01196 & 0.02642 & 0.00126 & 140 & 102 & 166 & 10 & 168 & 8 \\
\hline 13 & 27.95 & 448.81 & 917.88 & 0.49 & 0.04952 & 0.00247 & 0.1733 & 0.01182 & 0.02538 & 0.00123 & 173 & 113 & 162 & 10 & 162 & 5 \\
\hline 15 & 26.5 & 431.82 & 863.88 & 0.5 & 0.04803 & 0.00227 & 0.17132 & 0.01162 & 0.02587 & 0.00125 & 101 & 104 & 161 & 10 & 165 & 5 \\
\hline 16 & 6.78 & 105.62 & 227.81 & 0.46 & 0.04767 & 0.00444 & 0.16884 & 0.01743 & 0.02569 & 0.00137 & 83 & 201 & 158 & 15 & 163 & 6 \\
\hline 17 & 51.28 & 828.74 & 1707.37 & 0.49 & 0.0541 & 0.00214 & 0.19067 & 0.01161 & 0.02556 & 0.00121 & 375 & 89 & 177 & 10 & 163 & 4 \\
\hline 18 & 26.17 & 429.5 & 877.47 & 0.49 & 0.05596 & 0.0024 & 0.19354 & 0.01235 & 0.02509 & 0.0012 & 451 & 96 & 180 & 11 & 160 & 8 \\
\hline 19 & 13.26 & 211.65 & 429.66 & 0.49 & 0.05584 & 0.00441 & 0.19521 & 0.01797 & 0.02535 & 0.00133 & 446 & 168 & 181 & 15 & 161 & 4 \\
\hline 22 & 24.56 & 367.41 & 844.86 & 0.43 & 0.04878 & 0.00245 & 0.16722 & 0.01145 & 0.02486 & 0.00121 & 137 & 107 & 157 & 10 & 158 & 5 \\
\hline 23 & 9.82 & 163.25 & 325.98 & 0.50 & 0.05232 & 0.00355 & 0.18296 & 0.01447 & 0.02536 & 0.00126 & 299 & 146 & 171 & 12 & 161 & 5 \\
\hline 24 & 27.32 & 351.97 & 902.32 & 0.39 & 0.0515 & 0.00206 & 0.18541 & 0.01128 & 0.02611 & 0.00123 & 263 & 95 & 173 & 10 & 166 & 8 \\
\hline 25 & 61.86 & 749.89 & 2107.83 & 0.36 & 0.05229 & 0.00156 & 0.18216 & 0.0101 & 0.02527 & 0.0012 & 298 & 71 & 170 & 9 & 161 & 3 \\
\hline 28 & 12.68 & 173.15 & 430.87 & 0.4 & 0.05921 & 0.00523 & 0.20254 & 0.01961 & 0.02481 & 0.00133 & 575 & 202 & 187 & 17 & 158 & 8 \\
\hline 32 & 21.72 & 300.88 & 718.05 & 0.42 & 0.05122 & 0.00256 & 0.18355 & 0.01254 & 0.02599 & 0.00127 & 251 & 115 & 171 & 11 & 165 & 8 \\
\hline \multicolumn{17}{|c|}{ YP28-2-16 } \\
\hline 2 & 38.76 & 529.35 & 1285.9 & 0.41 & 0.05424 & 0.00174 & 0.19166 & 0.01012 & 0.02563 & 0.00108 & 381 & 73 & 178 & 9 & 163 & 7 \\
\hline 3 & 58.72 & 970.02 & 1947.29 & 0.5 & 0.04824 & 0.00146 & 0.16695 & 0.0086 & 0.0251 & 0.00106 & 111 & 69 & 157 & 7 & 160 & 7 \\
\hline 6 & 23.97 & 330.9 & 773.69 & 0.43 & 0.05205 & 0.00259 & 0.1847 & 0.01203 & 0.02574 & 0.00111 & 288 & 121 & 172 & 10 & 164 & 4 \\
\hline 7 & 30.93 & 735.09 & 992.41 & 0.74 & 0.0489 & 0.00231 & 0.16567 & 0.01047 & 0.02457 & 0.00107 & 143 & 112 & 156 & 9 & 156 & 7 \\
\hline 9 & 25.43 & 472.51 & 846.98 & 0.56 & 0.05143 & 0.00205 & 0.17576 & 0.01028 & 0.02478 & 0.00109 & 260 & 97 & 164 & 9 & 158 & 5 \\
\hline 10 & 25.03 & 374.35 & 846.73 & 0.44 & 0.04754 & 0.00254 & 0.16411 & 0.01096 & 0.02503 & 0.00108 & 77 & 122 & 154 & 10 & 159 & 7 \\
\hline 11 & 31.23 & 674.5 & 969.95 & 0.7 & 0.05237 & 0.00197 & 0.1858 & 0.01041 & 0.02573 & 0.00111 & 302 & 77 & 173 & 9 & 164 & 7 \\
\hline 12 & 30.37 & 469.11 & 995.36 & 0.47 & 0.04817 & 0.00165 & 0.17009 & 0.00938 & 0.02561 & 0.00109 & 107 & 71 & 159 & 8 & 163 & 7 \\
\hline 13 & 53.97 & 878.18 & 1782.61 & 0.49 & 0.05038 & 0.00133 & 0.17523 & 0.00872 & 0.02523 & 0.00106 & 212 & 55 & 164 & 8 & 161 & 3 \\
\hline 17 & 34.31 & 829.25 & 1086.9 & 0.76 & 0.05007 & 0.002 & 0.17229 & 0.01013 & 0.02496 & 0.00108 & 198 & 95 & 161 & 9 & 159 & 7 \\
\hline 18 & 44.36 & 1085.2 & 1339.04 & 0.81 & 0.04956 & 0.00202 & 0.1765 & 0.01034 & 0.02583 & 0.00112 & 174 & 96 & 165 & 9 & 164 & 2 \\
\hline 19 & 43.44 & 718.98 & 1415.64 & 0.51 & 0.05381 & 0.00196 & 0.1887 & 0.01051 & 0.02543 & 0.00109 & 363 & 85 & 176 & 9 & 162 & 7 \\
\hline 20 & 29.25 & 453.45 & 974.32 & 0.47 & 0.05078 & 0.00178 & 0.17584 & 0.00967 & 0.02512 & 0.00109 & 231 & 78 & 164 & 8 & 160 & 7 \\
\hline 21 & 26.99 & 404.76 & 903.86 & 0.45 & 0.05141 & 0.0021 & 0.18217 & 0.0107 & 0.0257 & 0.00111 & 259 & 90 & 170 & 9 & 164 & 4 \\
\hline 22 & 45.97 & 750.09 & 1497.59 & 0.5 & 0.05443 & 0.00197 & 0.18803 & 0.0105 & 0.02506 & 0.00107 & 389 & 78 & 175 & 9 & 160 & 7 \\
\hline 23 & 60.34 & 1008.4 & 2062.34 & 0.49 & 0.05166 & 0.00158 & 0.17432 & 0.00919 & 0.02447 & 0.00105 & 270 & 67 & 163 & 8 & 156 & 4 \\
\hline 24 & 46.04 & 1176.2 & 1390.86 & 0.85 & 0.04997 & 0.00166 & 0.17282 & 0.00926 & 0.02508 & 0.00106 & 194 & 75 & 162 & 8 & 160 & 7 \\
\hline 25 & 22.28 & 309.04 & 730.91 & 0.42 & 0.05014 & 0.00184 & 0.17786 & 0.01002 & 0.02573 & 0.0011 & 201 & 81 & 166 & 9 & 164 & 6 \\
\hline 27 & 60.25 & 2007.1 & 1733.54 & 1.16 & 0.04958 & 0.0012 & 0.17172 & 0.00835 & 0.02512 & 0.00107 & 176 & 58 & 161 & 7 & 160 & 7 \\
\hline 29 & 31.38 & 535.36 & 1009.31 & 0.53 & 0.05255 & 0.00177 & 0.18457 & 0.00995 & 0.02547 & 0.00109 & 309 & 80 & 172 & 9 & 162 & 7 \\
\hline 30 & 38.08 & 484.21 & 1289.54 & 0.38 & 0.04965 & 0.00189 & 0.17296 & 0.00983 & 0.02527 & 0.00108 & 179 & 91 & 162 & 9 & 161 & 5 \\
\hline 32 & 20.31 & 264.97 & 668.73 & 0.4 & 0.05217 & 0.00246 & 0.18645 & 0.0117 & 0.02592 & 0.00113 & 293 & 94 & 174 & 10 & 165 & 7 \\
\hline 33 & 37.73 & 713.3 & 1195.59 & 0.6 & 0.05149 & 0.00175 & 0.18244 & 0.00996 & 0.0257 & 0.0011 & 263 & 68 & 170 & 9 & 164 & 6 \\
\hline 34 & 65.63 & 1634.4 & 2123.01 & 0.77 & 0.05131 & 0.00153 & 0.18014 & 0.00938 & 0.02546 & 0.00108 & 255 & 60 & 168 & 8 & 162 & 7 \\
\hline
\end{tabular}



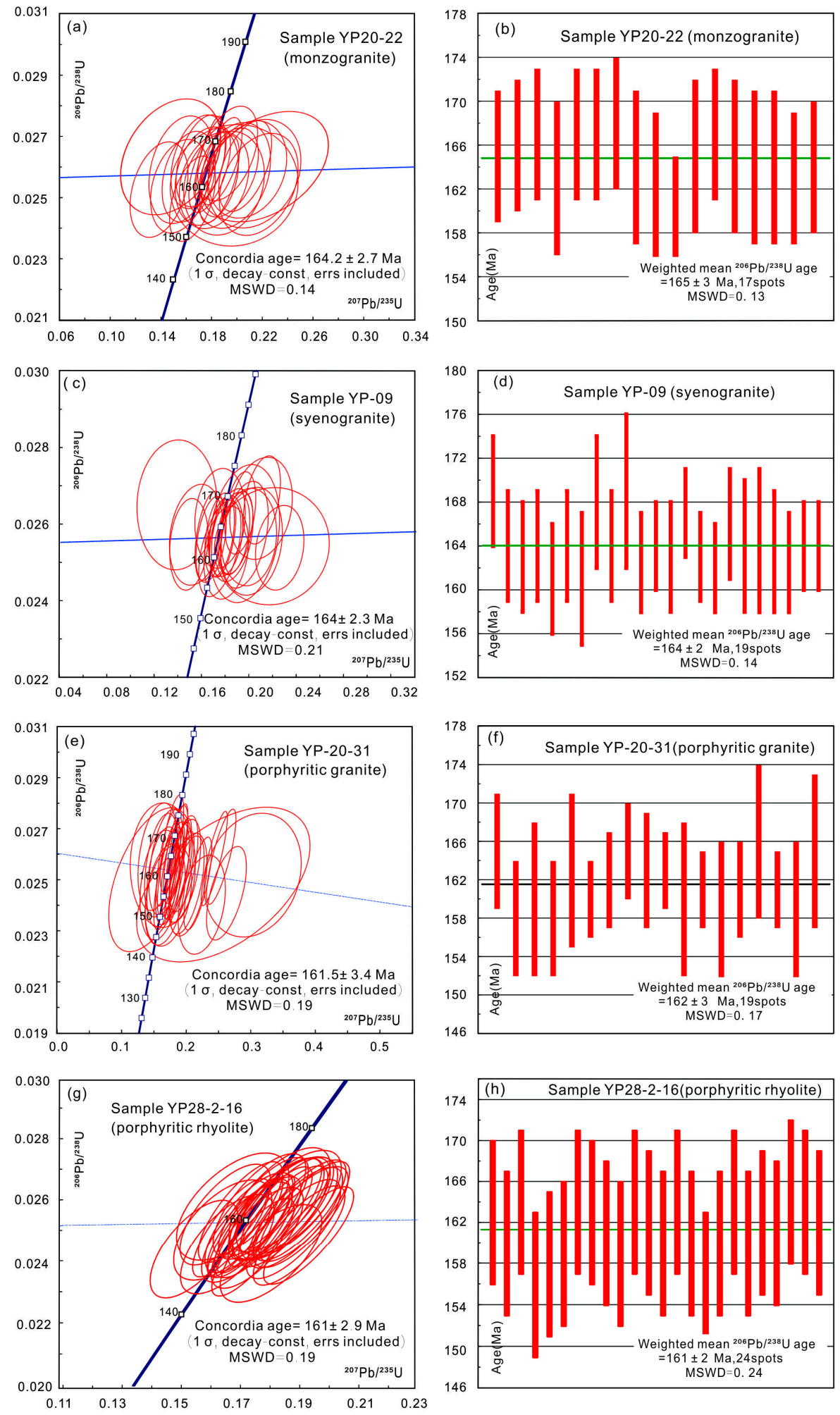

Figure 10. Zircon $\mathrm{U}-\mathrm{Pb}$ concordia diagrams for main magmatic rocks: $(\mathbf{a}, \mathbf{b})$ monzogranite, $(\mathbf{c}, \mathbf{d})$ syenogranite, $(\mathbf{e}, \mathbf{f})$ porphyritic granite and $(\mathbf{g}, \mathbf{h})$ porphyritic rhyolite.

The Th and U concentrations of zircons extracted from Sample YP-09 (syenogranite) varied from 76.4 to $945.5 \mathrm{ppm}$ and 136.88 to $1435.6 \mathrm{ppm}$, respectively, with associated $\mathrm{Th} / \mathrm{U}$ ratios of 0.40 to 1.35 (Table 2). A total of 23 points were analyzed in the syenogranite, and three others were not on the concordance line. Excluding the points that were not on the concordance line, 20 zircons 
yielded concordant ${ }^{206} \mathrm{~Pb} / 238 \mathrm{U}$ ages between $161 \pm 5 \mathrm{Ma}$ and $168 \pm 8 \mathrm{Ma}$, with a weighted average age of $164 \pm 2 \mathrm{Ma}$ (MSWD = 0.14; Table 2 and Figure 10c,d). This average was interpreted to be the emplacement age of the syenogranite.

Zircon grains from Sample YP-20-31 (porphyritic granite) had U and Th contents between 105.62-749.89 and 185.24-2107.83 ppm, respectively, with associated $\mathrm{Th} / \mathrm{U}$ ratios of approximately 0.37-1.65 (Table 2 and Figure 10c). A total of 32 points in the sample were analyzed; the 19 dated grains yielded concordant ${ }^{206} \mathrm{~Pb} /{ }^{238} \mathrm{U}$ ages between $158 \pm 6 \mathrm{Ma}$ and $168 \pm 8 \mathrm{Ma}$, with a mean ${ }^{206} \mathrm{~Pb} /{ }^{238} \mathrm{U}$ age of $162 \pm 3 \mathrm{Ma}$ and an MSWD value of 0.17 (Table 2 and Figure 10e,f). We interpreted this mean age as the emplacement age of the granite porphyries. A total of 13 points were not concordant and were excluded from the age calculation (Table 2).

Zircon grains selected from Sample YP28-2-16 (porphyritic rhyolite) exhibited variable ${ }^{232} \mathrm{Th}$ (220-507 ppm) and ${ }^{238} \mathrm{U}$ (668.73-2123.01 ppm) concentrations, with typical magmatic Th/U ratios between $0.40-0.77$ (Table 2). A total of 34 points were selected from the porphyritic rhyolite, of which the 24 that were analyzed yielded ${ }^{206} \mathrm{~Pb} /{ }^{238} \mathrm{U}$ ages ranging from $156 \pm 7$ to $165 \pm 7 \mathrm{Ma}$. Excluding the 10 points that were not on the concordant line, the weighted mean age of the remaining 24 samples was $161 \pm 2 \mathrm{Ma}(\mathrm{MSWD}=0.24$; Table 2 and Figure 10h,f), which was interpreted as the emplacement age of porphyritic rhyolite.

\subsection{Re-Os Age}

The concentrations of Re and Os, as well as the Os isotopic composition of molybdenite from Dongbulage, are listed in Table 3. Since the molybdenite samples were extracted from different types of ores, the Re contents ranged widely, from 0.4896 to $101.6 \mu \mathrm{g} / \mathrm{g}$. The ${ }^{187} \mathrm{Os}$ and common Os concentrations of the dated samples ranged between $0.843-172.8 \mathrm{ng} / \mathrm{g}$ and $0.0003-1.0195 \mathrm{ng} / \mathrm{g}$, respectively (Table 3). Compared to the relatively high ${ }^{187}$ Os values $(0.843-172.8 \mathrm{ng} / \mathrm{g})$ for the dated samples, the common Os values $(0.0003-1.0195 \mathrm{ng} / \mathrm{g}$ ) were negligible (Table 3), indicating that the measured Os is monoisotopic $\left({ }^{187} \mathrm{Os}\right)$ and the product of ${ }^{187} \mathrm{Re}$ decay [40]. Therefore, the Re-Os chronometer is an efficient method for dating.

Table 3. Re-Os data of molybdenite from the Dongbulage deposit.

\begin{tabular}{|c|c|c|c|c|c|c|c|c|c|c|c|c|}
\hline \multirow[t]{2}{*}{$\begin{array}{c}\text { Sample } \\
\text { No. }\end{array}$} & \multirow[t]{2}{*}{$\begin{array}{l}\text { Mineralization } \\
\text { Types }\end{array}$} & \multirow[t]{2}{*}{$\begin{array}{l}\text { Weight } \\
\text { (g) }\end{array}$} & \multicolumn{2}{|c|}{$\mathrm{Re} / \mu \mathrm{g} \cdot \mathrm{g}^{-1}$} & \multicolumn{2}{|c|}{$\begin{array}{l}\text { Common } \\
\text { Os/ng. } g^{-1}\end{array}$} & \multicolumn{2}{|c|}{${ }^{187} \mathrm{Re} / \mu \mathrm{g} \cdot \mathrm{g}^{-1}$} & \multicolumn{2}{|c|}{${ }^{187}$ Os/ng. $\mathbf{g}^{-1}$} & \multicolumn{2}{|c|}{ Model Age (Ma) } \\
\hline & & & Measured & $2 \sigma$ & Measured & $2 \sigma$ & Measured & $2 \sigma$ & Measured & $2 \sigma$ & Measured & $2 \sigma$ \\
\hline YP-5 & VM & 0.02280 & 101.6 & 0.7 & 1.0195 & 0.2459 & 63.86 & 0.45 & 172.8 & 1.1 & 162.2 & 2.2 \\
\hline YP-6 & VM & 0.01047 & 18.22 & 0.16 & 0.0022 & 0.0718 & 11.45 & 0.10 & 31.06 & 0.20 & 162.6 & 2.4 \\
\hline DBLG-8* & DSM and BM & 0.04999 & 10.786 & 0.11 & 0.0052 & 0.0292 & 6.78 & 0.07 & 18.61 & 0.19 & 164.7 & 2.7 \\
\hline DBLG-6* & DSM and BM & 0.30009 & 0.4896 & 0.0046 & 0.0026 & 0.0015 & 0.3077 & 0.0029 & 0.843 & 0.0071 & 164.2 & 2.5 \\
\hline DBLG-35 * & DSM and BM & 0.03708 & 2.741 & 0.023 & 0.0065 & 0.0069 & 1.723 & 0.015 & 4.771 & 0.044 & 166.0 & 2.5 \\
\hline DBLG-36* & DSM and BM & 0.05048 & 6.344 & 0.056 & 0.0822 & 0.0108 & 3.988 & 0.035 & 11.14 & 0.10 & 167.5 & 2.5 \\
\hline DBLG-38* & DSM and BM & 0.05053 & 6.355 & 0.053 & 0.0031 & 0.0035 & 3.995 & 0.033 & 10.93 & 0.09 & 164.0 & 2.3 \\
\hline DBLG-39* & DSM and BM & 0.04992 & 0.6918 & 0.081 & 0.0003 & 0.0003 & 0.4348 & 0.051 & 1.216 & 0.019 & 167.6 & 3.5 \\
\hline
\end{tabular}

Notes: * Data from Li et al. (2017) [7]; VM = vein-type mineralization; DSM = disseminated and stockwork mineralization; $\mathrm{BM}=$ breccia mineralization.

The Re-Os dating of molybdenite extracted from disseminated and breccia mineralization yielded Re-Os model ages ranging from 164.2 to 167.6 Ma, and yielded an identical Re-Os model age of 162.2 Ma for ore-bearing vein-type mineralization hosted by fractures and faults (Figure 11a and Table 3). Model ages of molybdenites overlapped with each other within the measurement uncertainty, and Mo mineralization occurred for a short period of time (Table 3). Based on the combination of the molybdenite Re-Os data above, the ${ }^{187} \mathrm{Re}$ and ${ }^{187}$ Os data for molybdenite define a well-constrained isochron, yielding a regression age of $162.6 \pm 1.5 \mathrm{Ma}(\mathrm{MSWD}=3.70$; Figure $11 \mathrm{~b})$, which was virtually identical to the weighted mean age of $164.5 \pm 1.7 \mathrm{Ma}(\mathrm{MSWD}=2.50, \mathrm{n}=8$; Figure 11a). 

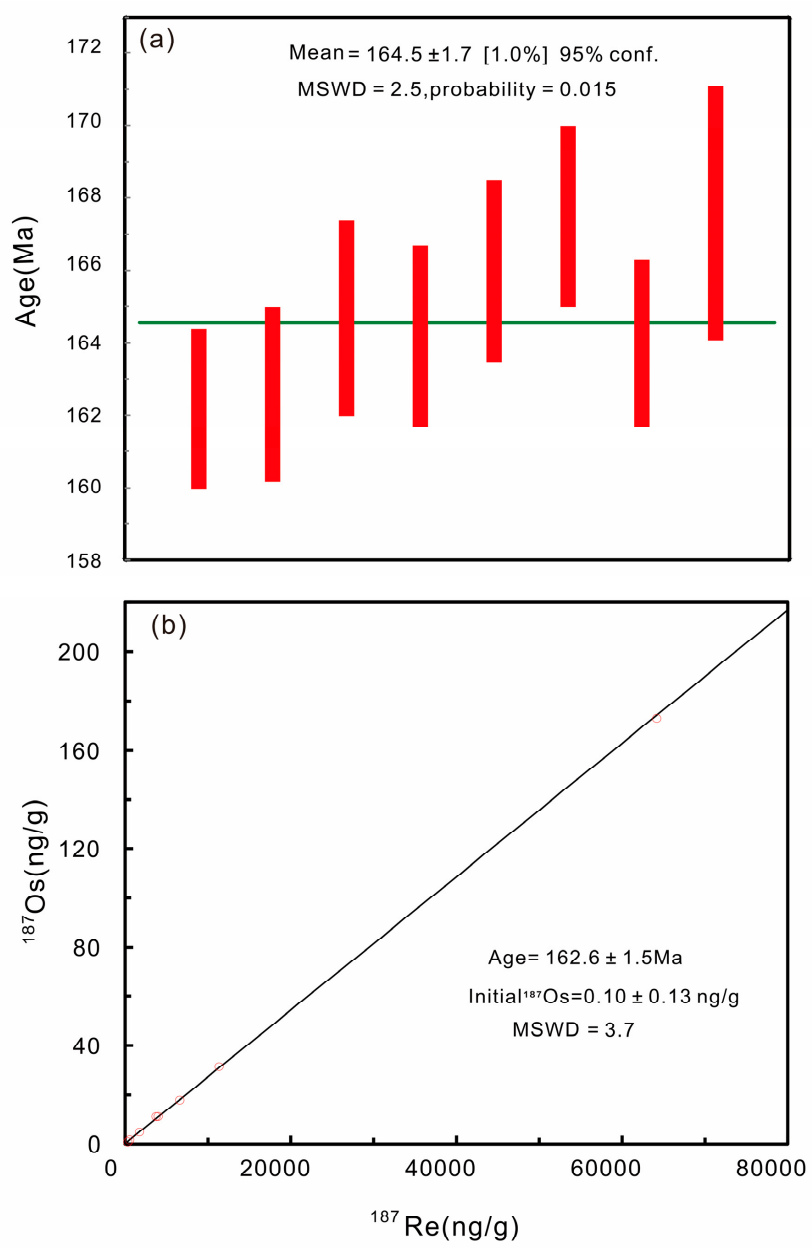

Figure 11. Re-Os isochron (a) and weighted average age (b) of molybdenite from Dongbulage Mo-polymetallic deposit.

\section{Discussion}

\subsection{Magma Evolution and Petrogenesis}

\subsubsection{Fractional Crystallization}

The Dongbulage Mo-polymetal deposit is temporally, spatially, and genetically related to the emplacement of the granitoids. Differentiations could play an important role in the Dongbulage Mo-rich magmatic evolution, and the process of fractional crystallization is recorded by the systematic distribution patterns of major and trace elements.

The Dongbulage granitoids exhibit a variation in chemical composition, and many major oxide elements (e.g., $\mathrm{TiO}_{2}, \mathrm{FeO}_{\mathrm{T}}, \mathrm{Al}_{2} \mathrm{O}_{3}, \mathrm{MgO}$, and $\mathrm{CaO}$ ) show good negative correlations with $\mathrm{SiO}_{2}$, with the exception of $\mathrm{K}_{2} \mathrm{O}, \mathrm{Na}_{2} \mathrm{O}$, and $\mathrm{MnO}$ (Figure 12). This suggests that fractional crystallization may have occurred during magma evolution, and complex processes influenced the compositions of the rocks. Fractional crystallization was also confirmed by the high differentiation index (DI) ranging from 81.75 to 94.76 (Table 1) and the obvious fractionation between LREE and HREE. 

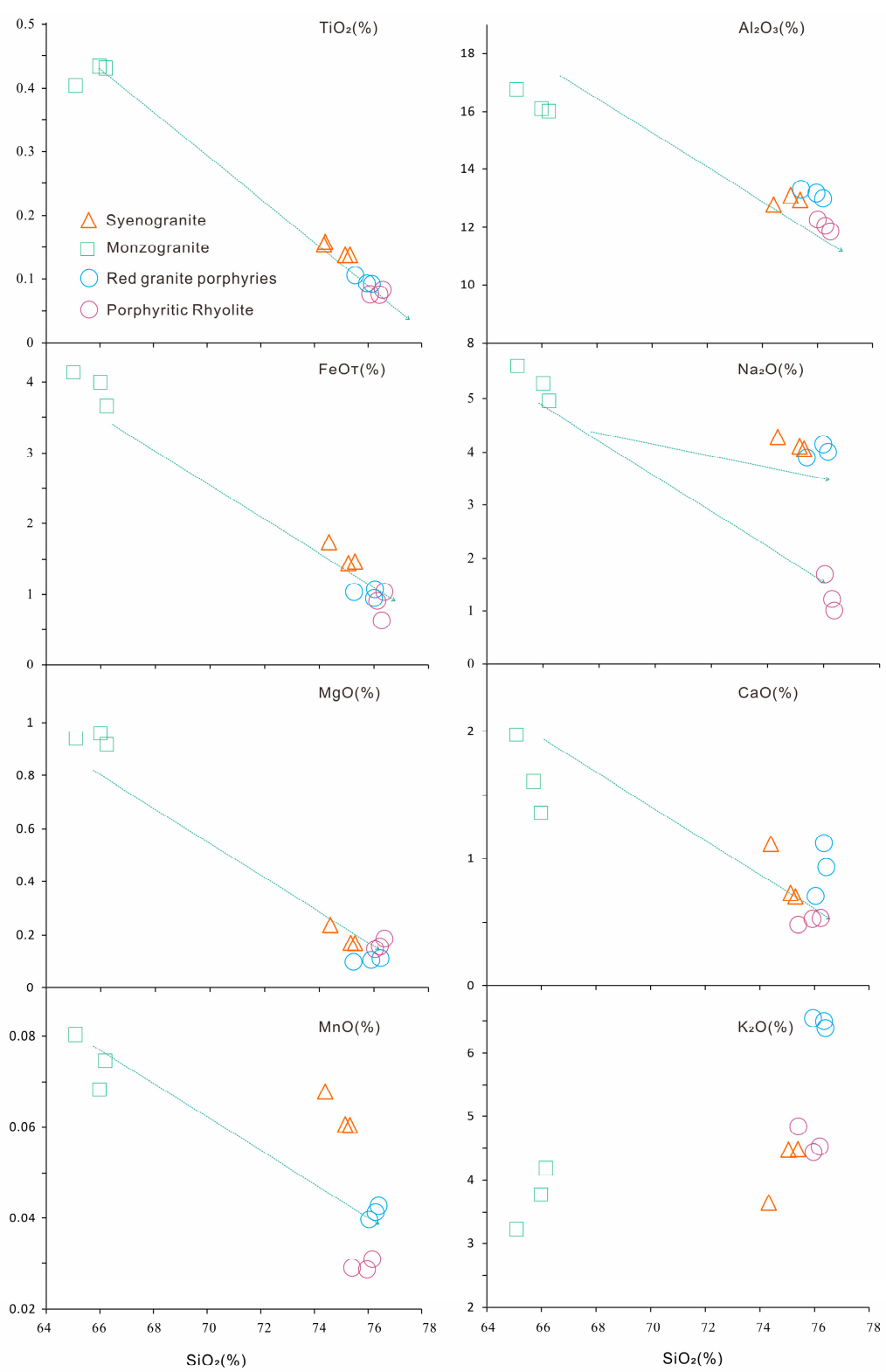

Figure 12. Harker diagrams for the granitoids at Dongbulage.

De Paolo (1981), Davidson et al. (1988), and Schiano et al. (2010) suggested that processes involved in partial melting and fractional crystallization can be identified from systematic changes in incompatible element concentrations and ratios [41-43]. The Ba (147.2-855.74 ppm) and Sr (83.19-241.10 ppm) concentrations of these rocks vary significantly, suggesting that the trace elements were obviously affected when hydrothermal processes are involved. Hence, all the dated samples only generally plot along a fractional crystallization trend in a $\mathrm{Ba} / \mathrm{Zr}$ versus Ba diagram (Figure 13a), and the same conclusion can be achieved using a Ba-Sr diagram, in which the linear correlation between $\mathrm{Sr}$ and $\mathrm{Ba}$ almost passes through the origin (Figure 13b), suggesting that the magmas that formed the Dongbulage granitoids underwent significant fractional crystallization, but the assimilation in hydrothermal processes also play a significant role in the petrogenesis.

The separation of feldspars played a significant role during the evolution of the Dongbulage stocks (Figure 13c-e). Plagioclase fractionation led to the depletions of $\mathrm{CaO}, \mathrm{Sr}$, and $\mathrm{Eu}$. On the other hand, negative Eu anomalies could be caused by the separation of K-feldspar, which can also explain the Ba depletion. Furthermore, the decrease in Ba with increase in $\mathrm{Rb}$, and with decreasing $\mathrm{Eu} / \mathrm{Eu}^{*}$, the decrease in $\mathrm{Sr}$ and increase in $\mathrm{Rb} / \mathrm{Sr}$. Trace element modeling also shows that biotite, minor apatite, 
and allanite are fractional phases (Figure 13c-f). Many researchers have suggested that peraluminous granitic rocks can be generated by the fractional crystallization of mafic parental magmas [44-46]; hence, we suggest that the peraluminous magmatic rocks around Dongbulage were successive products during the fractionation process of mafic parental magmas.
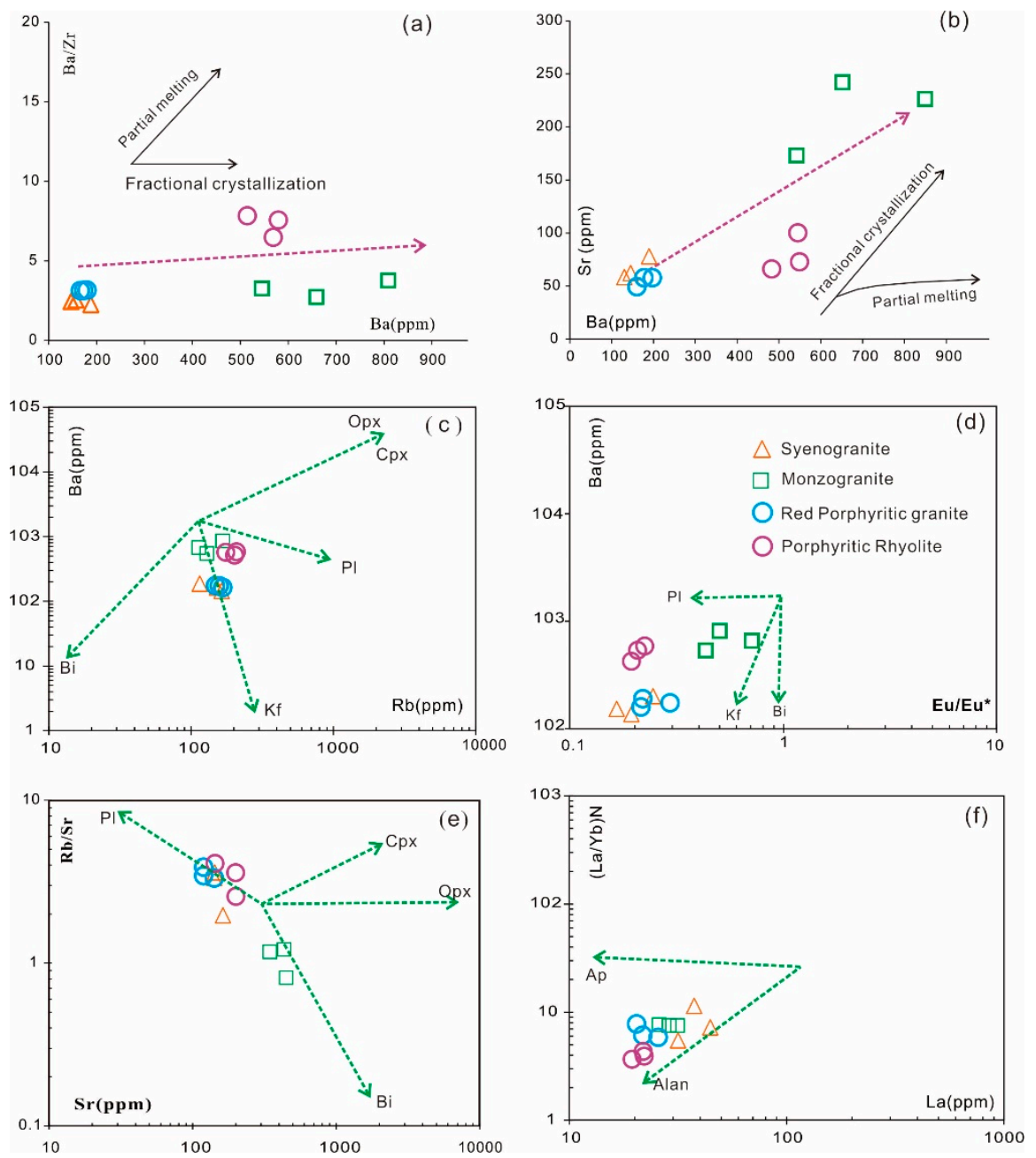

Figure 13. Geochemical plots for samples from Dongbulage showing variations in $\mathrm{Ba} / \mathrm{Zr}$ versus $\mathrm{Ba}$ (a) and $\mathrm{Sr}$ versus $\mathrm{Ba},(\mathbf{b})[43]$; and Ba versus $\mathrm{Rb},(\mathbf{c}) \mathrm{Ba}$ versus $\mathrm{Eu} / \mathrm{Eu}^{*}(\mathbf{d}), \mathrm{Rb} / \mathrm{Sr}$ versus $\mathrm{Sr},(\mathbf{e})(\mathrm{La} / \mathrm{Yb})_{\mathrm{N}}$ versus La, and (f) diagrams for the Dongbulage granitoids illustrating the fractional crystallization of plagioclase, K-feldspar, biotite, and minor allanite. Partition coefficients are from [37].

\subsubsection{Magma Types}

In the $(\mathrm{Zr}+\mathrm{Nb}+\mathrm{Ce}+\mathrm{Y})$ versus $\mathrm{FeO}_{\mathrm{T}} / \mathrm{MgO}$ and the $(\mathrm{Zr}+\mathrm{Nb}+\mathrm{Ce}+\mathrm{Y})$ versus $\left(\mathrm{K}_{2} \mathrm{O}+\mathrm{Na}_{2} \mathrm{O}\right) / \mathrm{CaO}$ diagrams, with the exception of the monzogranite samples, many of the magmatic rock samples around Dongbulage fell within the fractionated granite field (Figure 14a,b). However, monzogranites showed slightly high $(\mathrm{Zr}+\mathrm{Nb}+\mathrm{Ce}+\mathrm{Y})$ values ranging from approximately 476.73 to 493.92 , which is indicative of an A-type granite affinity (Figure 14a,b). Given that all of the magmatic rocks around Dongbulage had low 10,000 Ga/Al ratios (1.52-2.14) and low $\mathrm{Y}$ values (17.43-38.57 ppm), this actually indicates that these rocks were not A-type granites, but rather fractionated I or S-type granites (Figure 14c) [47].

The aluminum saturation index $(\mathrm{A} / \mathrm{CNK})$ of the dated samples was $<1.1$, with the exception of one sample (YP-7), suggesting that Dongbulage magmatic rocks are I-type granite (Figure 14c). Chappell et al. (1998) found that the P-content of S-type granites increases along with excess $\mathrm{Al}_{2} \mathrm{O}_{3}$ during fractional crystallization, while the P-content decreases to very low values in I-type granites [48]. 
The samples in our study had significantly low P-contents (approximately $0.01-0.14 \%$ ), which showed a negative correlation with $\mathrm{SiO}_{2}$, and was consistent with the typical evolution of I-type granites (Figure 14d). The geochemical affinity of I-type magmatic rocks was also further supported by low $\mathrm{Y}$ contents (17.43-38.57 ppm; Table 1) and $\mathrm{Rb} / \mathrm{Sr}$ ratios (1.39-2.94; Table 1), compared to A-type granites (75 for $\mathrm{Y}$ and a3.42 for $\mathrm{Rb} / \mathrm{Sr}$ ratios [47]). Thus, we conclude that the Dongbulage granitoids are a typical I-type, rather than an A-type or S-type intrusion.
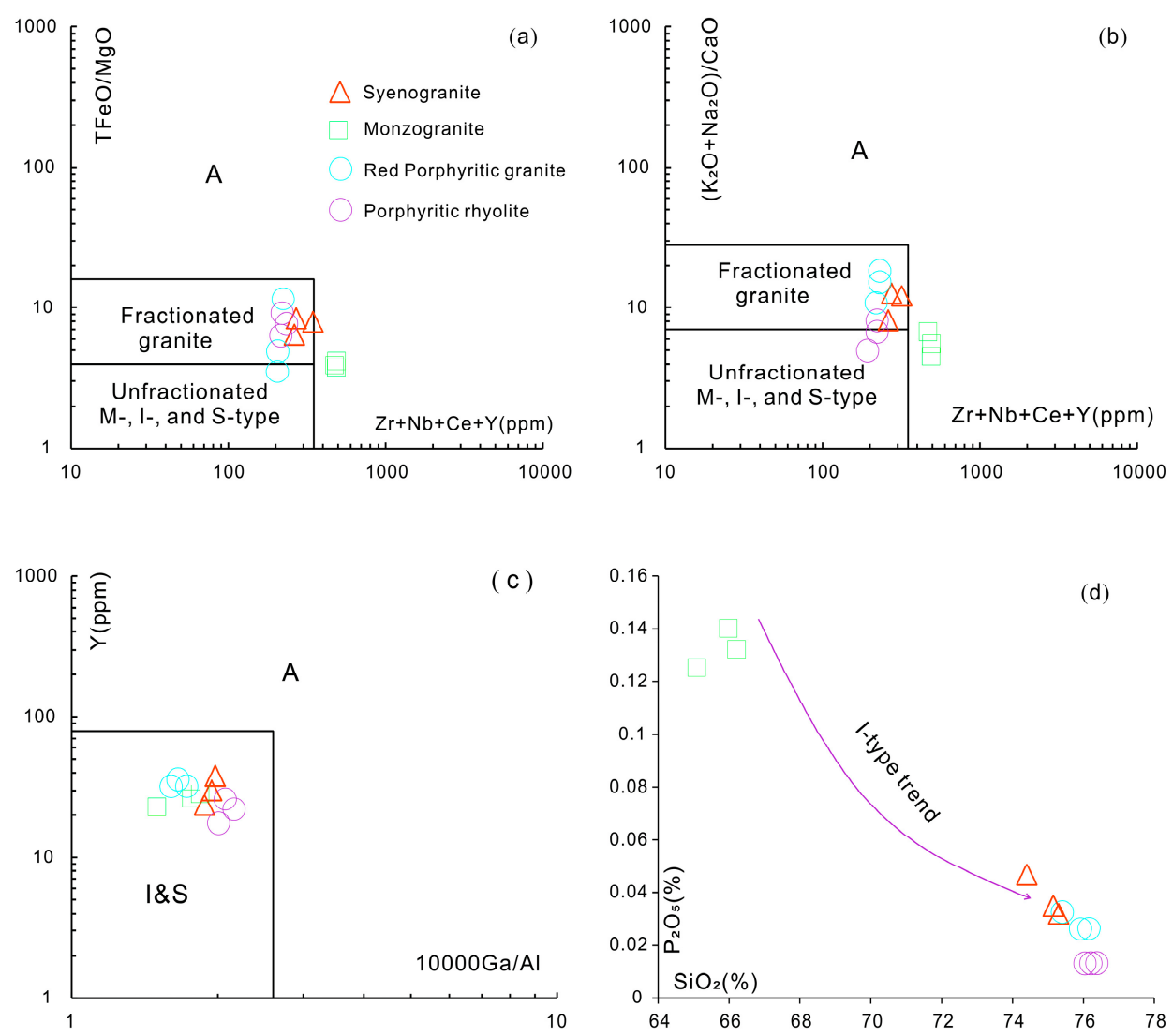

Figure 14. Dongbulage granites plot on diagrams (a) and (b) discriminating FG (fractionated granite) and OGT (unfractionated M-, I-, and S-type granites) granites from A-type granites [47]; (c) discriminating I-type and S-type granites from A-type granite [47] and (d) $\mathrm{SiO}_{2}$ vs. $\mathrm{P}_{2} \mathrm{O}_{5}$ diagram showing $\mathrm{P}$ variation vs. silica.

\subsubsection{Possible Sources}

Most scholars proposed that most of the highly fractionated granites in the CAOB are derived from a juvenile crust mixed with a minor proportion of Precambrian crust in their source rocks, and the magma source of granitoids may contain two member components that are mantle-derived and crust-derived [4,49-51]. Dongbulage granitoids have high contents of $\mathrm{SiO}_{2}$ and $\mathrm{K}_{2} \mathrm{O}$, and low abundances of $\mathrm{Cr}$ and $\mathrm{Ni}$ (Table 2), suggesting that they are mainly crust-derived magmas or highly evolved magmas. Generally, K-enriched calc-alkali granites are thought to be associated with mature subduction zones, which are confirmed by the $\mathrm{Th} / \mathrm{Yb}$ versus $\mathrm{Ta} / \mathrm{Yb}$ diagram (Figure 15a). Here, it can be seen that the Dongbulage granitoids plot near subduction zone compositions. In the $\mathrm{Rb} / \mathrm{Y}$ versus $\mathrm{Nb} / \mathrm{Y}$ and $\mathrm{Nb} / \mathrm{Y}$ versus $\mathrm{Th} / \mathrm{Y}$ diagrams (Figure $15 \mathrm{~b}, \mathrm{c}$ ), the samples from magmatic rocks at Dongbulage plot close to the lower part of the continental crust field, indicating that the source magmas were of deeper origin. In contrast, the $\mathrm{Th} / \mathrm{U}$ ratios for the Dongbulage granitoids were abnormally low, partly because granitic melts interact with primary mantle melts (1.20 to 4.05 [35]). These geochemical characteristics suggest that the source magmas of the Dongbulage granitoids had a deeper origin. 

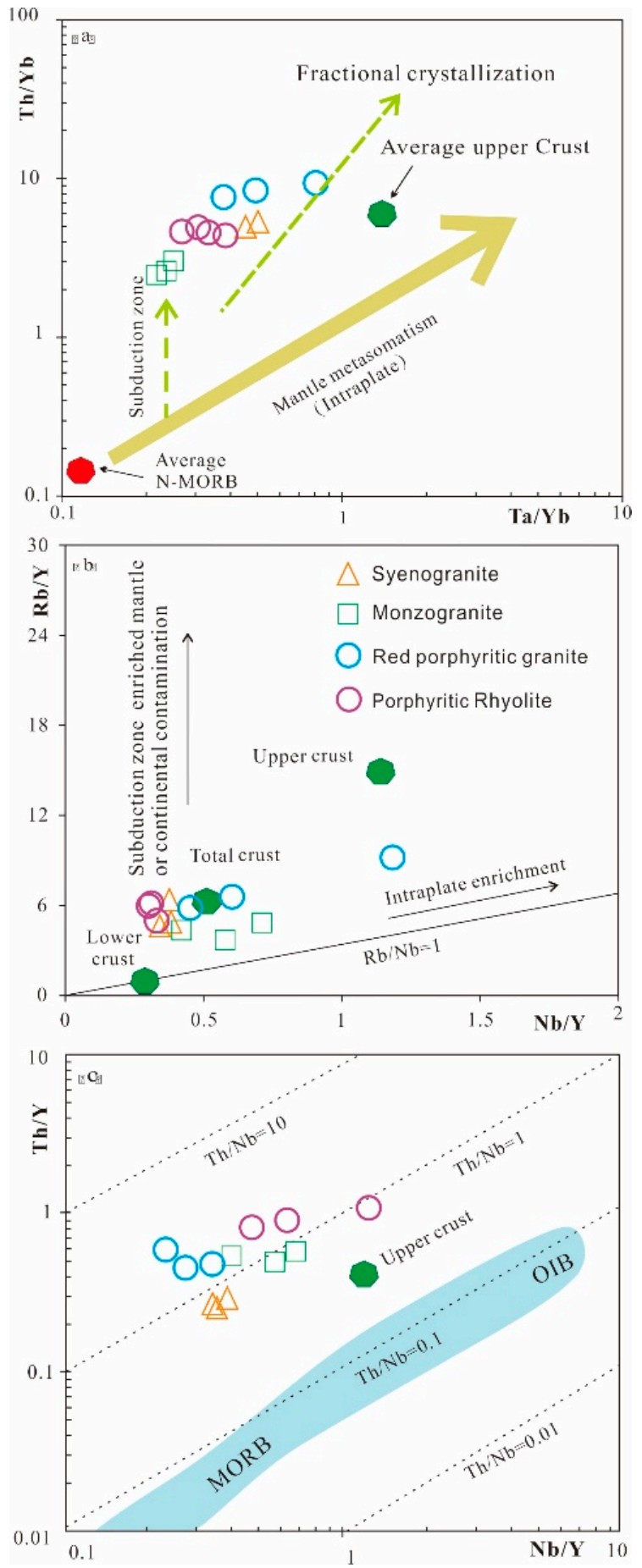

Figure 15. $\mathrm{Ta} / \mathrm{Yb}$ versus $\mathrm{Th} / \mathrm{Yb}$ diagram $(\mathbf{a}), \mathrm{Nb} / \mathrm{Y}$ versus $\mathrm{Rb} / \mathrm{Y}$ diagram $(\mathbf{b})$, and $\mathrm{Nb} / \mathrm{Y}$ versus $\mathrm{Th} / \mathrm{Y}$ diagram (c) of the samples from Dongbulage Mo-polymetallic deposit.

\subsection{Rhenium Concentrations in Molybdenite}

Berzina et al. (2005) suggested that the variations of Re content in molybdenites may be related to the composition of parent magmas, the concentration of Re in the ore-forming fluid, and variations of the physical and chemical crystallization conditions [52]. The Re contents in the dated molybdenites that were extracted from the Dongbulage deposit varied greatly, ranging from 0.50 to $101.6 \mathrm{ppm}$, indicating remarkable differences in metal sources. Mao et al. (1999) suggested that the Re contents of molybdenite might reflect the source of the deposits, with Re content decreasing from mantle $\left(\mathrm{n} \times 10^{-4}\right)$ 
to I-type $\left(\mathrm{n} \times 10^{-5}\right)$ to S-type $\left(\mathrm{n} \times 10^{-6}\right)$ granite-related deposits [53]. Stein et al. (2001) hypothesized that the Re concentrations in molybdenite provide clues as to the origin of a deposit, and that the deposits involving mantle contributions usually have higher Re contents than deposits derived from crust [54]. Therefore, the molybdenite Re contents at Dongbulage vary widely, implying a mixed crust-mantle origin for the ore materials (Figure 16).

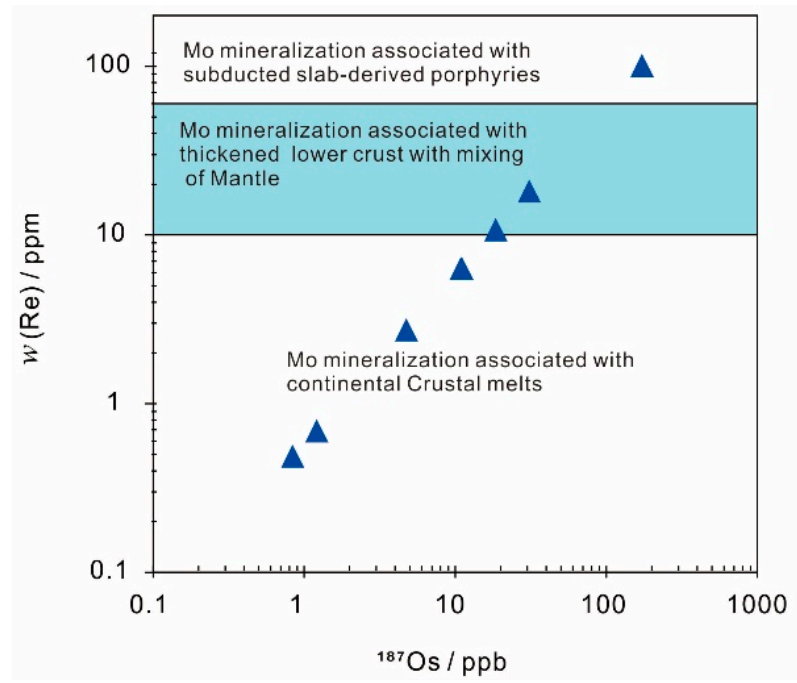

Figure 16. $w$ (Re) vs. ${ }^{187}$ Os diagram (modified from Chen et al., 2017 [55]) for Dongbulage Mo-polymetallic deposit.

\subsection{Ages of Magmatism and Metallogenesis}

Based on the geological field evidence, mineralization and alteration displayed horizontal zonal distributions centered on the porphyritic stocks at Dongbulage (Figure 3b), suggesting that mineralization in this area has a direct genetic relationship with porphyritic stocks. The accurate dating of magmatic-hydrothermal events is of fundamental importance when reconstructing the genetic evolution of porphyry systems and evaluating their duration.

According to the results of LA-ICP-MS zircon U-Pb dating, the ages of the felsic units at Dongbulage are $165 \pm 3 \mathrm{Ma}$ for monzogranite, $164 \pm 2$ Ma for syenogranite, $162 \pm 2 \mathrm{Ma}$ for red porphyritic granite, and $161 \pm 2 \mathrm{Ma}$ for porphyritic rhyolite (Figure 11). These dating results confirm a temporal correlation between the Buerhaotu granitic batholith (monzogranite and syenogranite) and adjacent small porphyritic stocks (porphyritic granite and porphyritic rhyolite), and indicate that the magmatism that occurred at Dongbulage continued for a protracted period ranging from approximately $165 \pm 3$ to $164 \pm 2 \mathrm{Ma}$, with granitic pluton intruding at approximately $165 \pm 3$ to $164 \pm 2 \mathrm{Ma}$ and late phase felsic subvolcanic-volcanic complexes intruding at approximately $162 \pm 3$ to $161 \pm 2$ Ma. Hence, we suggest that the ore-hosting subvolcanic complexes represent an apophysis of a larger intrusion at depth.

Molybdenite $\left(\mathrm{MoS}_{2}\right)$ is the main economic mineral in Dongbulage, and can be dated using the Re-Os method. The stability of Re-Os in molybdenite is thought to be highly robust through post-ore geological processes [56,57]. The dated samples yielded model ages of approximately 162.2-167.6 Ma, with a weighted average age of $164.5 \pm 1.7 \mathrm{Ma}$, initial ${ }^{187} \mathrm{Os}$ values ranging from approximately 0.4348 to $63.86 \mu \mathrm{g} / \mathrm{g}$, and MSWD = 2.50 (Figure 11a). In addition, the dated samples yielded a Re-Os isochron age of $162.6 \pm 1.5 \mathrm{Ma}(2 \sigma)$, with the initial ${ }^{187} \mathrm{Os}=0.10 \pm 0.13 \mathrm{ng} / \mathrm{g}$ and $\mathrm{MSWD}=3.70$ (Figure 11b). This ca. $162.6 \pm 1.5 \mathrm{Ma}$ age is coeval with the zircon $\mathrm{U}-\mathrm{Pb}$ ages of ore-hosting subvolcanic complexes, suggesting that the mineralization may be related to the later emplacement of subvolcanic complexes, as indicated in geological evidence described above. Hence, this new molybdenite Re-Os isochron age was interpreted as the ore-forming age, and this also indicates that the Mo-polymetallic mineralization at Dongbulage was formed during the Middle-Late Jurassic stage. 
Geochronological data published for the $\mathrm{Mo}(\mathrm{Pb}-\mathrm{Zn}-\mathrm{Ag})$ mineralization in the southern part of the Great Xing'an Range [55,58-72] are shown that this region records four stages for $\mathrm{Mo}(\mathrm{Pb}-\mathrm{Zn}-\mathrm{Ag})$ mineralization: (1) Late Permian (265 Ma), (2) Middle Triassic (244-235 Ma), (3) Middle-Late Jurassic (179-161 Ma), and (4) Late Jurassic-Early Cretaceous (147-132 Ma). The age of 162.6 $\pm 1.5 \mathrm{Ma}$ obtained in this study is also consistent with the Middle-Late Jurassic stage of Mo-polymetallic mineralization in the southern part of the Great Xing'an Range, such as the Lianhuashan $\mathrm{Cu}+\mathrm{Ag}+\mathrm{Mo}$ deposit with a zircon $\mathrm{U}-\mathrm{Pb}$ age of $161.8 \mathrm{Ma}$ and the Shuangjianzishan deposit with a pyrite Re-Os isochron age of $165 \pm 4 \mathrm{Ma}$, and slightly younger than the Meng'enTolgoi deposit, which had a muscovite Ar-Ar isochron age of $179 \pm 2 \mathrm{Ma}$ [58-60] (Figure 17).

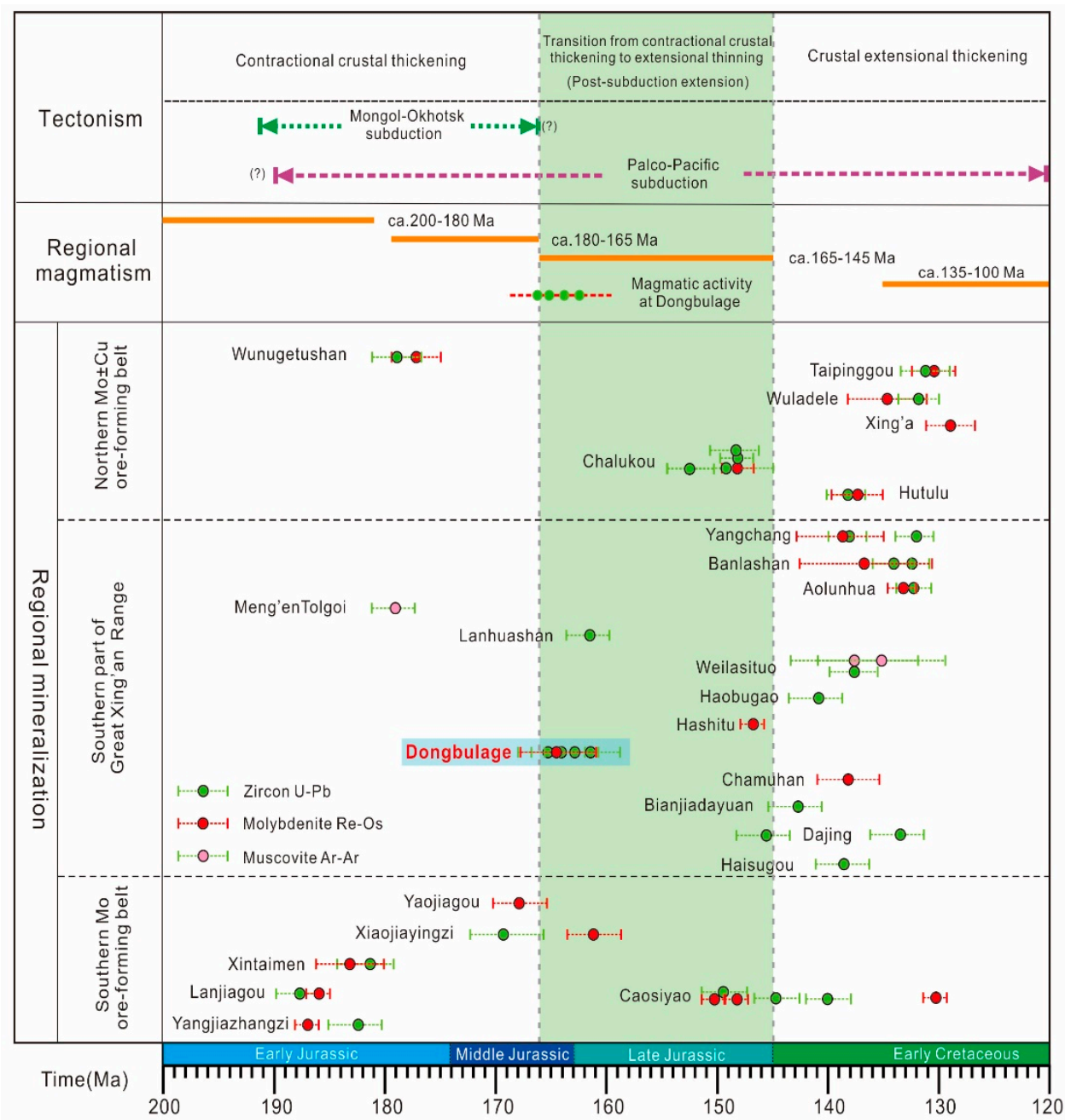

Figure 17. Time-scale showing the main plate tectonic events in $\mathrm{XMOB}$, the ages for references to magmatism in $\mathrm{XMOB}$, the ages for the main magmatic rocks around Dongbulage, and the Mo-polymetallic mineralizing events in XMOB. References to tectonism and magmatism: this study and $[18,55,58-75]$. References to mineralizing events: $[4,55,58-72,75-85]$ and this study. The green areas show the post-subduction extension environment; the dark yellow lines represent five major periods of magmatic activity, and the dots show age determinations obtained in previous research.

Combined with the Mo-dominant deposits in the northern and southern $\mathrm{Mo}( \pm \mathrm{Cu})$ ore-forming belts, examples of Middle-Late Jurassic deposits are the Wunugetushan deposit, with an Re-Os isochron age of $177.6 \pm 4.5 \mathrm{Ma}$, the Chalukou deposit, with an Re-Os isochron age of $148 \pm 1 \mathrm{Ma}$, the Yaojiagou deposit, with an Re-Os isochron age of $168.8 \pm 3.9 \mathrm{Ma}$, the Xiaojiayingzi deposit, with an Re-Os isochron age of $161.3 \pm 2.4 \mathrm{Ma}$, the Xintaimen deposit, with an Re-Os isochron age of 
$183 \pm 3 \mathrm{Ma}$, the Lanjiagou deposit, with an Re-Os isochron age of $186.5 \pm 0.7 \mathrm{Ma}$, the Yangiiazhangzi deposit, with an Re-Os isochron age of $187 \pm 2 \mathrm{Ma}$, and the Caosiyao deposit, with an Re-Os isochron age of $148.5 \pm 1.1 \mathrm{Ma}$ (Figure 17) [76-83]. These dates indicate that the Middle-Late Jurassic is an important Mo metallogenic stage in the region, although the peak of metallogenesis actually took place during Late Jurassic-Early Cretaceous periods (Figure 17). These ore-related granites are typically characterized by high degrees of fractionation, high silica content, and formations that were enriched by volatile elements such as $\mathrm{F}$ and $\mathrm{Li}$ [84-86].

\subsection{Tectonic Significance}

Even if the final closure time and location of the Paleo-Asian Ocean are still debated, the consensus is that the $\mathrm{XMOB}$ was a united continent during the Mesozoic period [87-91]. The geochronological data suggest that the Mesozoic magmatic activity in the XMOB have consisted of five major periods: 200-180 Ma related to a subduction-collision of the Mongol-Okhotsk Ocean, 180-165 Ma and 165-145 Ma with a post-collisional extensional setting, 145-135 Ma and 135-100 Ma formed during orogenic collapse coupled with back arc extension related to the subduction of the paleo-Pacific plate (Figure 17) [75]. Ouyang et al. (2015) pointed out that the magmatism and associated mineralization from the Late Jurassic to Early Cretaceous took place during the lithospheric extension resulting from the break-off of the south-dipping Mongol-Okhotsk oceanic slab at depth with the closure of the Mongol-Okhotsk Ocean, which also restricted the westward movement of the paleo-Pacific plate [5]. Based on our new results, the magmatic activities and related ore-forming events at Dongbulage took place between approximately $165 \pm 3$ and $161 \pm 2$ Ma (Figure 17), which is consistent with the period of the regional Middle-Late Jurassic magmatic activities (165-145 Ma). However, the tectonic setting of the Middle-Late Jurassic has controversial characteristics including: (1) Jurassic subduction of the paleo-Pacific plate [19,75]; (2) post-orogenic extension following the closure of the Mongolia-Okhotsk Ocean during the Late Jurassic-Early Cretaceous [21,62]; and (3) mantle plumes and mantle branches in an intraplate anorogenic environment $[20,92,93]$.

Given that the Middle-Late Jurassic tectonic setting in the XMOB is still unclear, the new geochemical and isotopic chronology of the magmatic rocks around Dongbulage can provide us with potential information regarding the geodynamic setting. According to the granitoid tectonic classification scheme based on major elements (the $\mathrm{SiO}_{2}$ versus $\mathrm{Al}_{2} \mathrm{O}_{3}$ and $\mathrm{R}_{1}-\mathrm{R}_{2}$ diagrams), most of the studied samples fell in the domains of post-orogenic granite and anorogenic granite (Figure 18a,b). The same conclusion is reached using the trace element discrimination diagrams: all the studied samples fell within the post-collisional granite (post-COLG) and volcanic arc granites (VAG) fields (Figure 18c,d). These tectonic setting discrimination diagrams suggest that either a post-collisional or post-orogenic geodynamic setting could represent the dominant tectonic environment from approximately $165 \pm 3$ to $161 \pm 2$ Ma at Dongbulage.
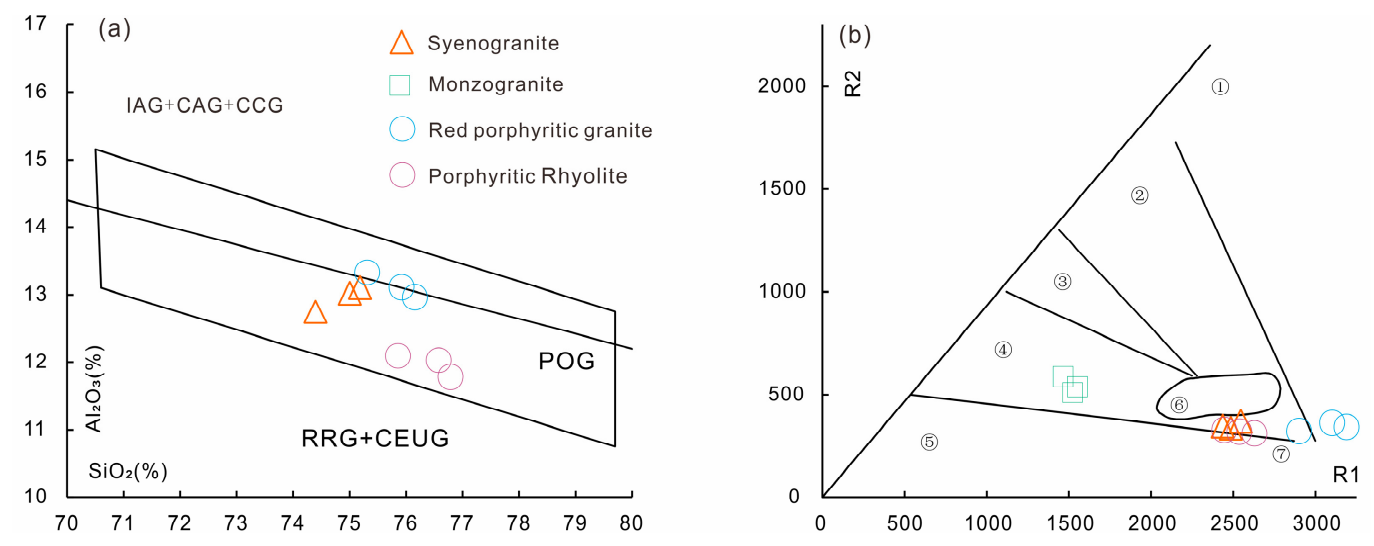

Figure 18. Cont. 

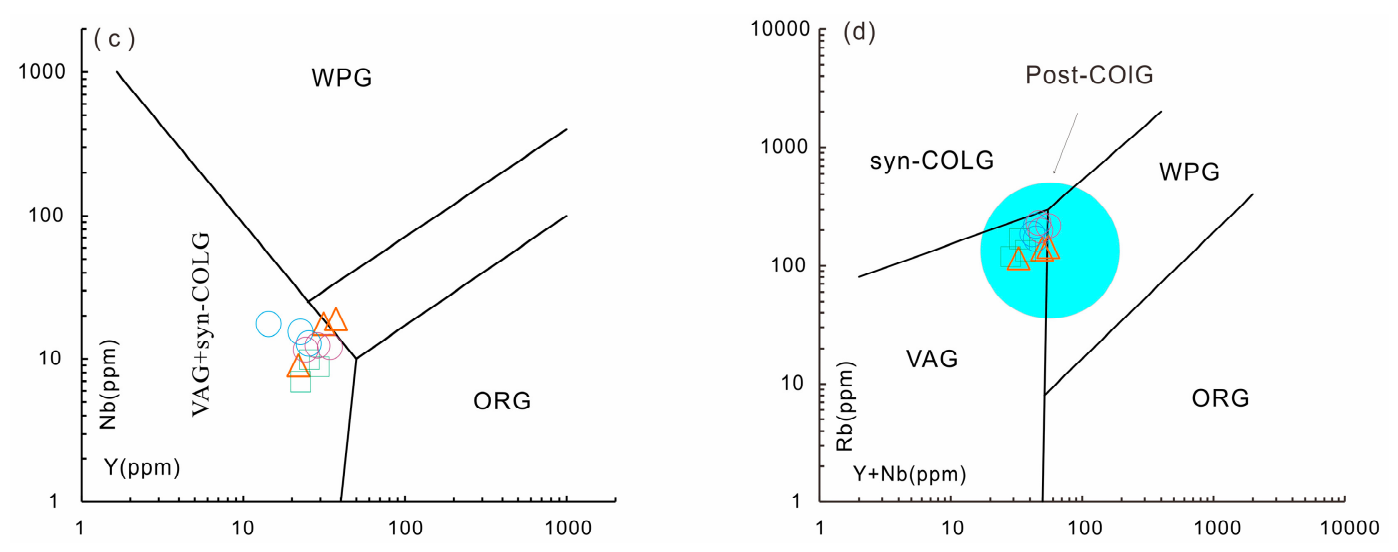

Figure 18. Major elements tectonic discrimination using (a) $\mathrm{Al}_{2} \mathrm{O}_{3}$ vs. $\mathrm{SiO}_{2}$ diagram and (b) $\mathrm{R} 1-\mathrm{R} 2$ multicationic variation diagram $\mathrm{R} 1=4 \mathrm{Si}-11(\mathrm{Na}+\mathrm{K})-2(\mathrm{Fe}+\mathrm{Ti})$ and $\mathrm{R} 2=6 \mathrm{Ca}+2 \mathrm{Mg}+\mathrm{Al}$ after [94]; (c) and (d) show rare elements tectonic discrimination diagrams after [95] and that of post-COLG in the $\mathrm{Rb}-\mathrm{Y}+\mathrm{Nb}$ ) diagram is adopted by [96]. CAG, continental arc granitoids; CCG, continental collision grantoids; CEUG, continental epeirogenic uplift granitoids; IAG, island-arc granitoids; ORG, oceanic ridge granites; POG, post-orogenic granitoids; post-COLG, post-collisional granites; RRG, rift-related granitoids; syn-COLG, syn-collisional granites; VAG, volcanic arc granites; WPG, within-plate granites; (1), mantle-differentiated granites; (2), pre-collisional granites; (3), post-collisional uplifting granites; (4), late-orogenic granites; (5), anorogenic granites; (6), syn-collisional granites; (7), post-orogenic granites.

Kravchinsky et al. (2012) proposed that the Mongol-Okhotsk Ocean may have closed gradually from west to east during the Permian-Early Cretaceous [97]. Recent studies have shown that the Mongol-Okhotsk Ocean was closed during the Middle Jurassic, and some Middle Jurassic-Early Cretaceous granitoids in the XMOB may be related to the post-orogenic collapse of the Mongol-Okhotsk orogen (Figure 17) [21,98-102]. According to Wang et al.(2015) [75], Middle-Late Jurassic (166-155 Ma) volcanic rocks west of the Songliao Basin belong to the high-K calc-alkaline series, which was formed during the collapse or delamination of a thickened continental crust associated with the evolution of the Mongol-Okhotsk suture belt. The evidence implies that the Middle-Late Jurassic magmatism in the XMOB may have been genetically related to the Mongol-Okhotsk orogenic event. However, much previous research data have indicated that magmatism and metallogeny are closely related to the subduction of the paleo-Pacific plates under the Eurasian continent [103], although these data overestimate the importance of the relationship between the subduction of the paleo-Pacific plate and magmatism in the XMOB. Even if the Middle-Late Jurassic magmatism in the region is active under different tectonic regimes, the consensus is that the Dongbulage granites and the associated $\mathrm{Mo}-\mathrm{Pb}-\mathrm{Zn}$ mineralization were formed in an extensional tectonic setting (Figure 17).

Therefore, the Middle-Late Jurassic Dongbulage magmatic rocks that most likely formed in a post-orogenic setting, which may have resulted from the combined influence of post-orogenic gravitational collapse and paleo-Pacific plate subduction, and perhaps been dominated by the former.

\subsection{Implications for the Formation of the Dongbulage Deposit}

Fluid inclusion studies from the Dongbulage deposit show that ores associated with Mo mineralization were deposited from an aqueous, high saline ( 63.9 eq. wt. $\% \mathrm{NaCl})$, high-temperature (approximately $534-312{ }^{\circ} \mathrm{C}$ ) fluid, indicating that the ore-forming fluid was mainly derived from magmatic water [7]. New Re-Os model ages are similar to the crystallization age of the ore-bearing porphyritic stocks around Dongbulage; therefore, the Mo-polymetallic temporally and genetically linked with a porphyry-cryptoexplosive breccia igneous system.

The concentrations of Mo in siliceous melts of a rhyolitic composition are low, and the enrichment of Mo in these melts is possibly achieved through fractional crystallization and the interaction and movement of magmatic-hydrothermal fluids [104-106]. Furthermore, Audétat (2010) suggested that 
Mo enrichment in ore-forming magma seems to occur by fractional crystallization rather than fluid transfer from associated mafic magmas [102]. The Dongbulage magmatic rocks have high differentiation indices (81.75-94.76), together with increasingly negative $\delta$ Eu anomalies (0.72-0.17), high values of incompatible trace elements (e.g., $\mathrm{Zr}, \mathrm{Ce}$, and $\mathrm{Rb}$ ) and low values of compatible trace elements (e.g., $\mathrm{Sr}$ and $\mathrm{CaO}$ ). This evidence indicates a fractional crystallization process during the evolution of ore-forming magma. Hence, we conclude that Mo content may have gradually increased in conjunction with the differentiation and evolution of magma at Dongbulage.

Most granitoids hosted by Mo-polymetallic deposits in the XMOB are highly fractionated. Examples include porphyritic granites hosting the giant Wunugetushan porphyry $\mathrm{Cu}-\mathrm{Mo}$ deposit and Chalukou porphyry Mo deposit in the northern Great Xing'an Range; porphyritic monzonitic granite and granodiorite hosting the Aolunhua, Haolibao porphyry $\mathrm{Cu}-\mathrm{Mo}$ deposit and Banlashan porphyry in the southern Great Xing'an Range; and monzonitic granite and granitic porphyries hosting the Caosiyao, Chaganhua porphyry Mo deposit in the northern margin of the North China Craton $[22,47,50,58,65,66,107]$. These granitoids are highly fractionated high-K calc-alkaline I-type and/or A-type granites, and they are geochemically characterized by enrichment of the LILEs (Ba, Rb, $\mathrm{U}$, and $\mathrm{Th}$ ) and $\mathrm{Pb}$, and depletion of the HFSEs ( $\mathrm{Nb}, \mathrm{Ta}$, and Ti) and HREE [22,47]. It should be noted that the highly fractionated I-type magmatic rocks at Dongbulage are members of the Mo-hosting granitoids in the XMOB.

Based on the available data, porphyry Mo deposits are directly associated with small volumes of porphyry emplaced as stocks, which is a part of relatively long-lived multiphase magmatic intrusion. The size of the magma chamber is a key factor forming an economic porphyry Mo deposit; due to the low saturation concentration of Mo in granitic melt, at least several tens of $\mathrm{km}^{3}$ of magma are required to concentrate large amounts of metals to produce an economic porphyry deposit. It can be calculated that at least several tens of $\mathrm{km}^{3}$ of magma were required to form the intermediate to large Mo deposits [108]. However, Mo-polymetallic mineralization at Dongbulage was mainly hosted by subvolcanic rocks (porphyritic granite and porphyritic rhyolite) and coeval breccia pipes (Figure 3). Such small stocks could not provide the total volume of Mo-polymetallic metal found at Dongbulage. Based on the essentially identical bulk-rock geochemical and isotopic data, we deduced that the highly fractionated I-type porphyritic granite and porphyritic rhyolite are part of the Buerhaotu granitic batholith, which provided much of the metal in the process of ore-forming hydrothermal evolution. In other words, magmatic rocks associated with Dongbulage Mo-polymetallic mineralization make up precursor pluton and ore-hosted subvolcanic complexes, and were emplaced over an interval of at least approximately four million years, between $165 \pm 3$ and $161 \pm 2$ Ma. Multiple pulses of intrusions can extend the life of a magmatic-hydrothermal system to a few million years. Harris et al. (2008) suggested that episodic replenishment is essential to ensure the longevity of a magmatic-hydrothermal system or its repeated reactivation beyond approximately one to two million years [109]. Therefore, the highly fractionated magma, along with the prolonged magmatic-hydrothermal interaction, jointly contributed to the formation of the Dongbulage deposit.

\section{Conclusions}

The Dongbulage is a porphyry deposit hosted by and genetically associated with the multiphase composite igneous body around Dongbulage. Geochemical studies show that porphyritic stocks at the Dongbulage deposit are highly fractionated I-types granites with negative Eu anomalies.

The new zircon $\mathrm{U}-\mathrm{Pb}$ data indicate that the ages of the magmatism at Dongbulage are identical within error and lasted for a period of time, ranging from $165 \pm 3$ to $161 \pm 2 \mathrm{Ma}$, with granitic pluton intruding at approximately $165 \pm 3$ to $164 \pm 2$ Ma and late-phase felsic subvolcanic complexes intruding at approximately $162 \pm 3$ to $161 \pm 2 \mathrm{Ma}$. The molybdenite Re-Os isochron age for different types of ores is $162.6 \pm 1.5 \mathrm{Ma}$, which is in accordance with previous zircon $\mathrm{U}-\mathrm{Pb}$ age determinations of magmatic rocks in the area. 
We propose that ore-hosting subvolcanic complexes represent an apophysis of a larger metal-rich intrusion at depth, which recorded a Middle-Late Jurassic Mo-rich felsic magma event during post-orogenic extension that followed the Mongol-Okhotsk Ocean closure coeval with the paleo-Pacific plate subduction.

Author Contributions: Conceptualization, S.J. and Y.L.; Data curation, Q.L.; Formal analysis, Q.L.; Funding acquisition, S.J., F.W. and C.C.; Investigation, F.W., and C.C.; Project administration, S.J.; Writing-original draft, F.W and C.C.

Funding: This work was jointly supported by National Key R\&D Program of China (2017YFC0601303), National Natural Science Foundation of China (41873051), Graduate demonstration course of Hebei province (KCJSX2018089) and Doctoral Scientific Research Foundation of Hebei GEO University (BQ2018032).

Acknowledgments: I sincerely appreciate the great support and assistance provided by Xiang Guo.

Conflicts of Interest: The authors declare no conflict of interest.

\section{References}

1. Sinclair, W.D. Porphyry deposits. In Mineral Deposits of Canada: A Synthesis of Major Deposit-Types, District Metallogeny, the Evolution of Geological Provinces, and Exploration Methods; Geological Association of Canada, Mineral Deposits Division, Special Publication: St. John's, NL, Canada, 2007; pp. 223-243.

2. Sengör, A.M.C.; Natal'In, B.A. Turkic-type orogeny and its role in the making of the continental crust. Annu. Rev. Earth Planet. Sci. 1996, 24, 263-337. [CrossRef]

3. Chen, Y.C.; Zhu, Y.S.; Xiao, K.Y.; Zhang, X.H.; Mei, Y.X.; Yan, S.H.; Liu, Y.L.; Song, G.G.; Li, C.J.; Wang, Y.Y.; et al. Division of minerogenic provinces (belts) in China. Miner. Depos. 2006, S1, 1-6. (In Chinese)

4. Wang, F.X.; Bagas, L.; Jiang, S.H.; Liu, Y.F. Geological, geochemical, and geochronological characteristics of Weilasituo Sn-polymetal deposit, Inner Mongolia, China. Ore Geol. Rev. 2017, 80, 1206-1229. [CrossRef]

5. Ouyang, H.G.; Mao, J.W.; Zhou, Z.H.; Su, H.M. Late Mesozoic metallogeny and intracontinental magmatism, southern Great Xing'an Range, northeastern China. Gondwana Res. 2015, 27, 1153-1172. [CrossRef]

6. Liu, Y.F.; Jiang, S.H. Mo mineralization in Xing'an-Mongolian orogen and north margin of China Craton: Review, question and a preliminary genetic model. Miner. Depos. 2017, 36, 557-594. (In Chinese)

7. Li, L.M.; Xie, Y.L.; Li, F.G.; Jia, L.; Chen, W.; Wang, Y.; Li, Z. Molybdenite Re-Os age and characteristics of ore-forming fluid of the Dongbulage Mo-Pb-Zn deposit, Inner Mongolia. Geotecton. Metallog. 2017, 41, 108-121. (In Chinese)

8. Wang, H.Z.; Mo, X.X. An outline of the tectonic evolution of China. Episodes 1995, 18, 6-16.

9. Jahn, B.M.; Wu, F.Y.; Chen, B. Granitoids of the Central Asian Orogenic Belt and continental growth in the Phanerozoic. Tran. Royal Soc. Edinburgh Earth Sci. 2000, 350, 181-193. [CrossRef]

10. Xu, B.; Zhao, P.; Wang, Y.; Liao, W.; Luo, Z.; Bao, Q.; Zhou, Y. The pre-Devonian tectonic framework of Xing'an-Mongolia orogenic belt (XMOB) in north China. J. Asian Earth Sci. 2015, 97, 183-196. [CrossRef]

11. Bureau of Geology and Mineral Resources of Inner Mongolia (BGMRIM). Regional Geology of Nei Mongol (Inner Mongolia) Autonomous Region; The memoirs of geological servey 25; Geological Publishing House: Beijing, China, 1991; p. 725. (In Chinese)

12. Wu, F.Y.; Zhao, G.C.; Sun, D.Y.; Wilde, S.A.; Yang, J.H. The Hulan Group: Its role in the evolution of the Central Asian Orogenic Belt of NE China. Asian Earth Sci. 2007, 30, 542-556. [CrossRef]

13. Zhang, X.Z.; Ma, Y.X.; Chi, X.G.; Zhang, F.X.; Sun, Y.W.; Guo, Y.; Zeng, Z. Discussion on Phanerozoic tectonic evolution in Northeastern China. Jilin Univ. (Earth Sci. Ed.) 2012, 42, 1269-1285. (In Chinese)

14. Pei, F.P.; Xu, W.L.; Yang, D.B.; Zhao, Q.G.; Liu, X.M.; Hu, Z.C. Zircon U-Pb geochronology of basement metamorphic rocks in the Songliao Basin. Chin. Sci. Bull. 2007, 52, 942-948. [CrossRef]

15. Zhou, X.H.; Ying, J.F.; Zhang, L.C.; Zhang, Y.T. The petrogenesis of Late Mesozoic volcanic rock and the contributions from ancient micro-continents: Constraints from the zircon U-Pb dating and $\mathrm{Sr}-\mathrm{Nd}-\mathrm{Pb}-\mathrm{Hf}$ isotopic systematics. Earth Sci. J. China Univ. Geosci. 2009, 34, 1-10. (In Chinese)

16. Zhou, J.B.; Wilde, S.A.; Zhang, X.Z.; Ren, S.M.; Zheng, C.Q. Early Paleozoic metamorphic rocks of the Erguna block in the Great Xing' an Range, NE China: Evidence for the timing of magmatic and metamorphic events and their tectonic implications. Tectonophysics 2011, 499, 105-117. [CrossRef] 
17. Mao, J.W.; Wang, Y.T.; Zhang, Z.H.; Yu, J.J.; Niu, B.G. Geodynamic settings of Mesozoic large-scale mineralization in the North China and adjacent areas: Implication from the highly precise and accurate ages of metal deposits. Sci. China Ser. D. 2003, 33, 838-851. [CrossRef]

18. Zhao, Y.; Xu, G.; Zhang, S.H.; Yang, Z.Y.; Zhang, Y.Q.; Hu, J.M. Yanshanian movement and conversion of tectonic regimes in East Asia. Earth Sci. Front. 2004, 11, 319-328. (In Chinese)

19. Ge, W.C.; Wu, F.Y.; Zhou, C.Y.; Zhang, J.H. Porphyry Cu-Mo deposits in the eastern Xing'an-Mongolian Orogenic Belt: Mineralization ages and their geodynamic implications. Chin. Sci. Bull. 2007, 52, 3416-3427. [CrossRef]

20. Pirajno, F.; Ernst, R.E.; Borisenko, A.S.; Fedoseev, G.; Naumov, E.A. Intraplate magmatism in Central Asia and China and associated metallogeny. Ore Geol. Rev. 2009, 35, 114-131. [CrossRef]

21. Xu, W.L.; Pei, F.P.; Wang, F.; Meng, E.; Ji, W.Q.; Yang, D.B.; Wang, W. Spatial-temporal relationships of Mesozoic volcanic rocks in NE China: Constraints on tectonic overprinting and transformations between multiple tectonic regimes. Asian Earth Sci. 2013, 74, 167-193. [CrossRef]

22. Wang, Y.H.; Zhao, C.B.; Zhang, F.F.; Liu, J.J.; Wang, J.P.; Peng, R.M.; Liu, B. SIMS zircon U-Pb and molybdenite Re-Os geochronology, Hf isotope, and whole-rock geochemistry of the Wunugetushan porphyry Cu-Mo deposit and granitoids in NE China and their geological significance. Gondwana Res. 2015, 28, 1228-1245. [CrossRef]

23. Nie, F.J.; Li, Q.F.; Liu, C.H.; Ding, C.W. Geology and origin of Ag-Pb-Zn deposits occurring in the Ulaan-Jiawula metallogenic province, northeast Asia. Asian Earth Sci. 2015, 97, 424-441. [CrossRef]

24. Zhongxing Geological Exploration Co. Ltd. (ZXGE). Prospecting Report of the Dongbulage Mo-Pb-Zn Deposit in the Wulan Mining Area, West Ujimqin, Inner Mongolia; Mining prospecting report; Zhongxing Geological Exploration Co. Ltd. (ZXGE): Wulan, China, 2010; pp. 1-103. Unpublished Report. (In Chinese)

25. Liu, X.; Gao, S.; Diwu, C.; Yuan, H.; Hu, Z. Simultaneous in-situ determination of U-Pb age and trace elements in zircon by LA-ICP-MS in $20 \mu \mathrm{m}$ spot size. Chin. Sci. Bull. 2007, 52, 1257-1264. [CrossRef]

26. Andersen, T. Correction of common lead in $\mathrm{U}-\mathrm{Pb}$ analyses that do not report ${ }^{204} \mathrm{~Pb}$. Chem. Geol. 2002, 192, 59-79. [CrossRef]

27. Ludwig, K.R. User's Manual for Isoplot 3.00: A Geochronological Toolkit for Microsoft Excel; Berkeley Geochronology Center Special Publication: Berkeley, CA, USA, 2003; pp. 1-70.

28. Du, A.D.; He, H.L.; Yin, N.W. A study of the rhenium-osmium geochronometry of molybdenites. Acta Geol. Sin. English Edi. 1995, 8, 171-181.

29. Du, A.D.; Wang, S.X.; Sun, D.; Zhao, D.M.; Liu, D.Y. Precise Re-Os dating of molybdenite using Carius tube, NTIMS and ICPMS. In Mineral Deposits at the Beginning of the 21st Century, Proceedings of the Joint 6th Biennial SGA-SEG Meeting, Krakov, Poland, 26-29 August 2001; Piestrzynski, A., Ed.; Swets and Zeitlinger Publishers: Lisse, The Netherlands, 2001; pp. 405-407.

30. Du, A.D.; Wu, S.Q.; Sun, D.Z.; Wang, S.X.; Qu, W.J.; Markey, R.; Stein, H.; Morgan, J.; Malinovskiy, D. Preparation and certification of Re-Os dating reference materials: Molybdenite HLP and JDC. Geostand. Geoanal. Res. 2004, 28, 41-52. [CrossRef]

31. Shirey, S.B.; Walker, R.J. Carius tube digestion for low-bank rhenium-osmium analysis. Anal. Chem. 1995, 67, 2136-2141. [CrossRef]

32. Stein, H.J.; Markey, R.J.; Morgan, J.W.; Du, A.; Sun, Y. Highly precise and accurate Re-Os ages for molybdenite from the East Qinling molybdenum belt, Shaanxi Province, China. Econ Geol. 1997, 92, 827-835. [CrossRef]

33. Smoliar, M.L.; Walker, R.J.; Morgan, J.W. Re-Os ages of group IA, IIA, IVA and IVB iron meteorites. Science 1996, 271, 1099-1102. [CrossRef]

34. Thornton, C.P.; Tuttle, O.F. Chemistry of igneous rocks. 1. Differentiation index. Am. J. Sci. 1960, 258, 664-684. [CrossRef]

35. Sun, S.S.; McDonough, W.F. Chemical and isotopic systematic of oceanic basalts: Implications for mantle composition and processes. In Magmatism in the Ocean Basins; Saunders, A.D., Norry, M.J., Eds.; Geological Society, London, Special Publications: London, UK, 1989; Volume 42, pp. 313-345.

36. Meinert, L.D. Compositional Variation of Igneous Rocks Associated with Skarn Deposits-Chemical Evidence for a Genetic Connection between Petrogenesis and Mineralization; Mineralogical Association of Canada: Québec, QC, Canada, 1995; pp. 401-418.

37. Rollinson, H.R. Using Geochemical Data: Evaluation, Presentation, Interpretation; Pearson Education: London, UK, 1993. 
38. Maniar, P.D.; Piccoli, P.M. Tectonic discrimination of granitoids. Geol. Soc. Am. Bull. 1989, 101, $635-643$. [CrossRef]

39. Taylor, S.R. The application of trace element data to problems in petrology. Phys. Chem. Earth. 1965, 6, 133-213. [CrossRef]

40. Raith, J.G.; Stein, H.J. Re-Os dating and sulfur isotope composition of molybdenite from tungsten deposits in western Namaqualand, South Africa: Implication for ore genesis and the timing of metamorphism. Mine. Depos. 2000, 35, 741-753.

41. Paolo, D.J. Trace element and isotopic effects of combined wall-rock assimilation and fractional crystallization. Earth Planet. Sci. Lett. 1981, 53, 189-202.

42. Davidson, J.P.; Dungan, M.A.; Ferguson, K.M.; Colucci, M.T. Crust-magma interactions and the evolution of arc magmas: The San Pedro-Pellado Volcanic complex, southern Chilean Andes. Geology 1988, 15, 443-446. [CrossRef]

43. Schiano, P.; Monzier, M.; Eissen, J.P.; Martin, H.; Koga, K.T. Simple mixing as the major control of the evolution of volcanic suites in the Ecuadorian Andes. Contrib. Miner. Petrol. 2010, 160, 297-312. [CrossRef]

44. Phillips, L.W. Assessing measurement error in key informant reports: A methodological note on organizational analysis in marketing. J. Mark. Res. 1981, 18, 395-415. [CrossRef]

45. Mittlefehldt, D.W.; Miller, C.F. Geochemistry of the Sweetwater Wash Pluton, California: Implications for "anomalous" trace element behavior during differentiation of felsic magmas. Geochim. Cosmochim. Acta 1983, 47, 109-124. [CrossRef]

46. Clemens, J.D. S-type granitic magmas-Petrogenetic issues, models and evidence. Earth Sci. Rev. 2003, 61, 1-18. [CrossRef]

47. Whalen, J.B.; Currie, K.L.; Chappell, B.W. A-type granites: Geochemical characteristics, discrimination and petrogenesis. Contrib. Miner. Petrol. 1987, 95, 407-419. [CrossRef]

48. Chappell, B.W.; Bryant, C.J.; Wyborn, D.; White, A.J.R.; Williams, I.S. High- and low temperature I-type granites. Resour. Geol. 1998, 48, 225-235. [CrossRef]

49. Jahn, B.M.; Wu, F.; Capdevila, R.; Martineau, F.; Zhao, Z.; Wang, Y. Highly evolved juvenile granites with tetrad REE patterns: The Woduhe and Baerzhe granites from the Great Xing'an Mountains in NE China. Lithos 2001, 59, 171-198. [CrossRef]

50. Jahn, B.M.; Capdevila, R.; Liu, D.Y.; Vernon, A.; Badarch, G. Sources of Phanerozoic granitoids in the transect Bayanhongor-Ulaan Baatar, Mongolia: Geochemical and Nd isotopic evidence, and implications for Phanerozoic crustal growth. J. Asian Earth Sci. 2004, 23, 629-653. [CrossRef]

51. Jiang, S.H.; Bagas, L.; Hu, P.; Han, N.; Chen, C.L.; Liu, Y.; Kang, H. Zircon U-Pb ages and Sr-Nd-Hf isotopes of the highly fractionated granite with tetrad REE patterns in the Shamai tungsten deposit in eastern Inner Mongolia, China: Implications for the timing of mineralization and ore genesis. Lithos 2016, 261, 322-339.

52. Berzina, A.N.; Sotnikov, V.I.; Economou-Eliopoulos, M.; Eliopoulos, D.G. Distribution of rhenium in molybdenite from porphyry Cu-Mo and Mo-Cu deposits of Russia (Siberia) and Mongolia. Ore Geol. Rev. 2005, 26, 91-113. [CrossRef]

53. Mao, J.W.; Zhang, Z.C.; Zhang, Z.H.; Du, A. Re-Os isotopic dating of molybdenites in the Xiaoliugou W (Mo) deposit in the northern Qinling mountains and its geological significance. Geochim. Cosmochim. Acta 1999, $36,1815-1818$.

54. Stein, H.J.; Markey, R.J.; Morgan, J.W. The remarkable Re-Os chronometer in molybdenite: How and why it works. Terra Nova. 2001, 13, 479-486. [CrossRef]

55. Chen, Y.J.; Zhang, C.; Wang, P.; Pirajno, F.; Li, N. The Mo deposits of Northeast China: A powerful indicator of tectonic settings and associated evolutionary trends. Ore Geol. Rev. 2017, 81, 602-640. [CrossRef]

56. Stein, H.J.; Markey, R.J.; Morgan, J.W.; Hannah, J.L.; Zák, K.; Sundblad, K. Re-Os dating of shear-hosted Au deposits using molybdenite, in Papunen. Mine Depos. 1997, 313-317.

57. Frei, R.; Nägler, T.F.; Schöberg, R.; Kramers, J.D. Re-Os, Sm-Nd, U-Pb, and stepwise lead leaching isotope systematics in shear-zone hosted gold mineralization: Genetic tracing and age constraints of crustal hydrothermal activity. Geochim. Cosmochim. Acta 1998, 62, 1935-1936. [CrossRef]

58. Bai, L.A.; Sun, J.G.; Sun, Q.L.; Gu, A.L.; Zhao, K.Q.; Men, L.J. Ore-forming fluids and genesis of Lianhuashan $\mathrm{Cu}$ deposit in middle Da Hinggan Mountains. Mine Depos. 2012, 31, 1249-1258. (In Chinese) 
59. Liu, C.H.; Bagas, L.; Wang, F.X. Isotopic analysis of the super-large Shuangjianzishan Pb-Zn-Ag deposit in Inner Mongolia, China: Constraints on magmatism, metallogenesis, and tectonic setting. Ore Geol. Rev. 2016, 75, 252-267. [CrossRef]

60. Zhu, X.Q.; Zhang, Q.; He, Y.L.; Zhu, C.H.; Huang, Y. Hydrothermal source rocks of the Meng'entaolegai $\mathrm{Ag}-\mathrm{Pb}-\mathrm{Zn}$ deposit in the granite batholith, Inner Mongolia, China: Constrained by isotopic geochemistry. Geochem. J. 2006, 40, 265-275. [CrossRef]

61. Zeng, Q.D.; Liu, J.M.; Zhang, Z.L. Re-Os geochronology of porphyry molybdenum deposit in south segment of Da Hinggan Mountains, Northeast China. J. Earth Sci. 2010, 21, 392-401. [CrossRef]

62. Ruan, B.X.; Lu, X.B.; Liu, S.T.; Yang, W. Genesis of Bianjiadayuan Pb-Zn-Ag deposit in Inner Mongolia: Constraints from U-Pb dating of zircon and multi-isotope geochemistry. Miner. Depos. 2013, 32, 501-514. (In Chinese)

63. Zhao, Y.M.; Wang, D.W.; Zhang, D.Q.; Fu, X.Z.; Bao, X.P.; Ai, Y.F. Ore-Controlling Factors and Ore-Prospecting Models for Copper-Polymetallic Deposits in Southeastern Inner Mongolia; Seismological Publishing House: Beijing, China, 1994; pp. 1-234. (In Chinese)

64. Zeng, Q.D.; Liu, J.M.; Zhang, Z.L.; Jia, C.S.; Yu, C.M.; Ye, J.; Liu, H.T. Geology and lead-isotope study of the Baiyinnuoer $\mathrm{Zn}-\mathrm{Pb}-\mathrm{Ag}$ deposit, south segment of the Da Hinggan Mountains, Northeastern China. Resour. Geol. 2009, 59, 170-180. [CrossRef]

65. Jiang, S.H.; Nie, F.J.; Bai, D.M.; Liu, Y.F.; Liu, Y. Geochronology evidence for Indosinian mineralization in Baiyinnuoer Pb-Zn deposit of Inner Mongolia. Mine. Depo. 2011, 30, 787-798. (In Chinese)

66. Wang, M.Y.; He, L. Re-Os dating of molybdenites from Chamuhan W-Mo deposit, Inner Mongolia and its geological implications. Geotecton. Metallog. 2013, 37, 49-56. (In Chinese)

67. Shu, Q.H.; Lai, Y.; Wang, C.; Xu, J.J.; Sun, Y. Geochronology, geochemistry and Sr-Nd-Hf isotopes of the Haisugou porphyry Mo deposit, northeast China, and their geological significance. J. Asian Earth Sci. 2013, 79, 777-791. [CrossRef]

68. Zhai, D.G.; Liu, J.J.; Wang, J.P.; Yang, Y.Q.; Zhang, H.Y.; Wang, X.L.; Zhang, Q.B.; Wang, G.W.; Liu, Z.J. Zircon $\mathrm{U}-\mathrm{Pb}$ and molybdenite Re-Os geochronology, and whole-rock geochemistry of the Hashitu molybdenum deposit and host granitoids, Inner Mongolia, NE China. J. Asian Earth Sci. 2013, 79, 144-160. [CrossRef]

69. Zeng, Q.D.; Yang, J.H.; Zhang, Z.L.; Liu, J.M.; Duan, X.X. Petrogenesis of the Yangchang Mo-bearing granite in the Xilamulun metallogenic belt, NE China: Geochemistry, zircon U-Pb ages and $\mathrm{Sr}-\mathrm{Nd}-\mathrm{Pb}$ isotopes. Geol. Mag. 2013, 49, 1-14. [CrossRef]

70. Pan, X.F.; Guo, L.J.; Wang, S.; Xue, H.M.; Hou, Z.Q.; Tong, Y. Laser microprobe Ar -Ar dating of biotite from the Weilasituo Cu-Zn polymetallic deposit in Inner Mongolia. Acta Petrol. Mineralog. 2009, 28, 473-479. (In Chinese)

71. Chang, Y.; Lai, Y. Study of characteristics of ore-forming fluid and chronology in the Yindu Ag-Pb-Zn polymetallic ore deposit, Inner Mongolia. Acta Scientiarum Naturalium Universitatis Pekinensis 2010, 46, 581-593. (In Chinese)

72. Huang, D.H.; Du, A.D.; Wu, C.Y.; Liu, L.S.; Sun, Y.L.; Zou, X.Q. Metallochronology of molybdenum (-copper) deposits in the north China Platform: Re-Os age of molybdenite and its geological significance. Miner. Depos. 1996, 15, 365-373. (In Chinese)

73. Wang, F.X.; Sun, Z.J.; Pei, R.F.; Liu, Y.F.; Liu, C.H.; Jiang, S.H. The Geologic features and Genesis of Shuangjianzishan Ag-polymetallic Deposit, Balinzuo Qi, Inner Mongolia. Geol. Rev. 2016, 62, 1241-1256. (In Chinese)

74. Zhang, J.H.; Ge, W.C.; Wu, F.Y.; Wilde, S.A.; Yang, J.H.; Liu, X.M. Large-scale early Cretaceous volcanic events in the northern Great Xing'an Range, northeastern China. Lithos 2008, 102, 138-157. [CrossRef]

75. Wang, T.; Guo, L.; Zhang, L.; Yang, Q.; Zhang, J.; Tong, Y.; Ye, K. Timing and evolution of Jurassic-Cretaceous granitoid magmatism in the Mongol-Okhotsk belt and adjacent areas, NE Asia: Implications for transition from contractional crustal thickening to extensional thinning and geodynamic settings. J. Asian Earth Sci. 2015, 97, 365-392. [CrossRef]

76. Chen, Z.G.; Zhang, L.C.; Wan, B.; Wu, H.Y.; Cleven, N. Geochronology and geochemistry of the Wunugetushan porphyry Cu-Mo deposit in NE China, and their geological significance. Ore. Geol. Rev. 2011, 43, 92-105. [CrossRef] 
77. Liu, J.; Mao, J.W.; Wu, G.; Wang, F.; Luo, D.F.; Hu, Y.Q. Zircon U-Pb and molybdenite Re-Os dating of the Chalukou porphyry Mo deposit in the northern Great Xing'an Range, China, and its geological significance. J. Asian Earth Sci. 2014, 79, 696-709. [CrossRef]

78. Fang, J.Q.; Nie, F.J.; Zhang, K. Re-Os isotopic dating on molybdenite separates and its geological significance from the Yaojiagou molybdenum deposit, Liaoning Province. Acta Petrol. Sin. 2012, 28, 372-378. (In Chinese)

79. Dai, J.Z.; Mao, J.W.; Zhao, C.S.; Xie, G.Q.; Yang, F.Q.; Wang, Y.T. New U-Pb and Re-Os age data and the geodynamic setting of the Xiaojiayingzi Mo (Fe) deposit, Western Liaoning province, Northeastern China. Ore Geol. Rev. 2009, 35, 235-244. [CrossRef]

80. Zhang, Z.Z.; Wu, C.Z.; Gu, L.X.; Feng, H.; Zheng, Y.C.; Huang, J.H.; Li, J.; Sun, Y.L. Molybdenite Re-Os dating of Xintaimen molybdenum deposit in Yanshan-Liaoning Metallogenic Belt, North China. Miner. Depos. 2009, 28, 313-320. (In Chinese)

81. Shu, Q.H.; Jiang, L.; Lai, Y.; Lu, Y.H. Geochronology and fluid inclusion study of the Aolunhua porphyry Cu-Mo deposit in Arhorqin Area, Inner Mongolia. Acta Petrol. Sin. 2009, 25, 2601-2614. (In Chinese)

82. Tao, J.X.; Chen, Z.H.; Luo, Z.Z.; Xu, L.Q.; Hao, X.Y.; Cui, L.W. The Re-Os isotopic dating of molybdenite from the Wulandele molybdenum-copper polymetallic deposit in Sonid Zuoqi of Inner Mongolia and its geological significance. Rock Miner. Anal. 2009, 28, 249-253. (In Chinese)

83. Wu, G.; Li, X.Z.; Xu, L.Q.; Wang, G.R.; Liu, J.; Zhang, T.; Quan, Z.X.; Wu, H.; Li, T.G.; Chen, Y.C. Age, geochemistry, and $\mathrm{Sr}-\mathrm{Nd}-\mathrm{Hf}-\mathrm{Pb}$ isotopes of the Caosiyao porphyry Mo deposit in Inner Mongolia. China. Ore Geol. Rev. 2017, 81, 706-727. [CrossRef]

84. Yan, C.; Sun, Y.; Lai, Y. LA-ICP-MS zircon U-Pb and molybdenite Re-Os isotope ages and metallogenic geodynamic setting of Banlashan Mo deposit, Inner Mongolia. Mine. Depo. 2011, 30, 616-634. (In Chinese)

85. Zhang, C. Geology, Geochemistry and Metallogenic Evolution of Molybdenum Deposits in the Great Hinggan Range. Ph.D. Thesis, Peking University, Beijing, China, 2015. (In Chinese).

86. Zhang, C.; Li, N. Geochronology and zircon Hf isotope geochemistry of the granites at the giant Chalukou Mo deposit. NE China: Implication for tectonic setting. Ore Geol. Rev. 2017, 81, 780-793. [CrossRef]

87. Şengör, A.M.C.; Natal'in, B.A.; Burtman, V.S. Evolution of the Altaid tectonic collage and Palaeozoic crustal growth in Eurasia. Nature 1993, 364, 299-307. [CrossRef]

88. Xiao, W.J.; Windley, B.F.; Hao, J.; Zhai, M.G. Accretion leading to collision and the Permian Solonker suture, Inner Mongolia, China: Termination of the central Asian orogenic belt. Tectonics 2003, 22, 1069. [CrossRef]

89. Xiao, W.J.; Windley, B.F.; Huang, B.C.; Han, C.M.; Yuan, C.; Chen, H.L.; Sun, M.; Sun, S.; Li, J.L. End-Permian to mid-Triassic termination of the accretionary processes of the southern Altaids: Implications for the geodynamic evolution, Phanerozoic continental growth, and metallogeny of Central Asia. Int. J. Earth Sci. 2009, 98, 1189-1217. [CrossRef]

90. Wu, F.Y.; Sun, D.Y.; Ge, W.C.; Zhang, Y.B.; Grant, M.L.; Wilde, S.A.; Jahn, B.-M. Geochronology of the Phanerozoic granitoids in northeastern China. J. Asian Earth Sci. 2011, 41, 1-30. [CrossRef]

91. Wu, G.; Chen, Y.C.; Chen, Y.J.; Zeng, Q.T. Zircon U-Pb ages of the metamorphic supracrustal rocks of the Xinghuadukou Group and granitic complexes in the Argun massif of the northern Great Hinggan Range, NE China, and their tectonic implications. J. Asian Earth Sci. 2012, 49, 214-233. [CrossRef]

92. Niu, S.Y.; Nie, F.J.; Sun, A.Q.; Jiang, S.H. Mantle branch structure and silver polymetallic mineralization in the Da Hinggan Mountains, Inner Mongolia. J. Jilin Univ. 2011, 41, 1944-1958. (In Chinese)

93. Pirajno, F.; Zhou, T.F. Intracontinental porphyry and porphyry-skarn mineral systems in eastern China: Scrutiny of a special case "Made-in-China". Econ. Geol. 2015, 110, 603-629. [CrossRef]

94. Batchelor, R.A.; Bowden, P. Petrogenetic interpretation of granitoid rock series using multicationic parameters. Chem. Geol. 1985, 48, 43-55. [CrossRef]

95. Stern, R.J.; Gottfried, D. Discussion of the Paper 'Late Pan-African Magmatism and Crustal Development in Northeastern Egypt'. Geol. J. 1989, 24, 371-374. [CrossRef]

96. Pearce, J. Sources and settings of granitic rocks. Episodes 1996, 19, 120-125.

97. Kravchinsky, V.A.; Cogne, J.P.; Harbert, W.P.; Kuzmin, M.I. Evolution of the Mongol-Okhotsk Ocean as constrained by new palaeomagnetic data from the Mongol-Okhotsk suture zone, Siberia. Geophys. J. Int. 2002, 148, 34-57. [CrossRef]

98. Zorin, Y.A. Geodynamics of the western part of the Mongolia-Okhotsk collisional belt, Trans-Baikal region (Russia) and Mongolia. Tectonophysics 1999, 306, 33-56. [CrossRef] 
99. Cogné, J.P.; Kravchinsky, V.A.; Halim, N.; Hankard, F. Late Jurassic-Early Cretaceous closure of the Mongol-Okhotsk Ocean demonstrated by new Mesozoic palaeomagnetic results from the Trans-Baikal area (SE Siberia). Geophys. J. Int. 2005, 163, 813-832. [CrossRef]

100. Tomurtogoo, O.; Windley, B.F.; Kroner, A.; Badarch, G.; Liu, D.Y. Zircon age and occurrence of the Adaatsag ophiolite and Muron shear zone, central Mongolia: Constraints on the evolution of the Mongol-Okhotsk ocean, suture and orogeny. J. Geol. Soc. Lond. 2005, 162, 125-134. [CrossRef]

101. Deng, J.; Wang, Q.F. Gold mineralization in China: Metallogenic provinces, deposit types and tectonic framework. Gondwana Res. 2016, 36, 219-274. [CrossRef]

102. Yang, L.Q.; Deng, J.; Wang, Z.L.; Zhang, L.; Guo, L.N.; Song, M.C.; Zheng, X.L. Mesozoic gold metallogenic system of the Jiaodong gold province, eastern China. Acta Geosci. Sin. 2014, 30, 2447-2467. (In Chinese)

103. Dong, S.W.; Zhang, Y.Q.; Long, C.X.; Yang, Z.Y.; Ji, Q.; Wang, T.; Hu, J.M.; Chen, X.H. Jurassic tectonic revolution in China and new interpretation of the Yanshan movement. Acta Geol. Sin. 2007, 81, 1449-1461. (In Chinese)

104. Audétat, A. Source and Evolution of Molybdenum in the Porphyry Mo(-Nb) Deposit at Cave Peak, Texas. J. Petrol. 2010, 51, 1739-1760. [CrossRef]

105. Audétat, A.; Dolejs, D.; Lowenstern, J.B. Molybdenite saturation in silicic magmas: Occurrence and petrological implications. Petrology 2011, 52, 891-904. [CrossRef]

106. Christiansen, E.H.; Keith, J.D. Trace element systematics in silicic magmas: A metallogenic perspective. In Trace Element Geochemistry of Volcanic Rocks: Applications for Massive Sulphide Exploration; Geological Association of Canada, Short Course Notes; Wyman, D.A., Ed.; Geological Assn of Canada: St. John's, NL, Canada, 1996; pp. 115-151.

107. Liu, Y.F.; Nie, F.J.; Jiang, S.H.; Zhong, X.I.; Zhang, Z.G.; Xiao, W. Ore-forming granites from Chaganhua molybdenum deposit, central Inner Mongolia, China: Geochemistry, geochronology and petrogenesis. Acta Petrol. Sin. 2012, 28, 409-420. (In Chinese)

108. Lerchbaumer, L.; Audétat, A. The metal content of silicate melts and aqueous fluids in subeconomically Mo mineralized granites: Implications for porphyry Mo genesis. Econ. Geol. 2013, 108, 987-1013. [CrossRef]

109. Harris, A.C.; Dunlap, W.J.; Reiners, P.W.; Allen, C.M.; Cooke, D.R.; White, N.C. Multimillion-year thermal history of a porphyry copper deposit: Application of U-Pb, ${ }^{40} \mathrm{Ar} /{ }^{39} \mathrm{Ar}$ and (U-Th)/He chronometers, Bajo de la alumbrera copper-gold deposit, Argentina. Miner. Depos. 2008, 43, 295-314. [CrossRef]

(C) 2019 by the authors. Licensee MDPI, Basel, Switzerland. This article is an open access article distributed under the terms and conditions of the Creative Commons Attribution (CC BY) license (http://creativecommons.org/licenses/by/4.0/). 